Pontifícia Universidade Católica

\title{
A INTERAÇÃO TUTOR-ALUNO NO AMBIENTE DE EDUCAÇÃO A DISTÂNCIA: UM ESTUDO DE CASO
}

\section{Dissertação de Mestrado}

Dissertação apresentada ao Programa de PósGraduação em Estudos da Linguagem do Departamento de Letras da PUC-Rio como parte dos requisitos parciais para obtenção do título de Mestre em Letras/Estudos da Linguagem.

Orientador: Profa. Maria do Carmo Leite de Oliveira 
Pontifícia Universidade Católica $_{\text {a }}$ DO RIO DE JANEIRO

Deise de Lacerda Paiva

\begin{abstract}
A INTERAÇÃO TUTOR-ALUNO NO AMBIENTE DE EDUCAÇÃO A DISTÂNCIA: UM ESTUDO DE CASO
\end{abstract}

\author{
Profa. Maria do Carmo Leite de Oliveira \\ Orientadora \\ Departamento de Letras - PUC-Rio
}

Profa. Maria das Graças Dias Pereira

Departamento de Letras - PUC-Rio

Profa. Kátia Cristina do Amaral Tavares Departamento de Letras - UFRJ

Profa. Denise Berruezo Portinari Coordenadora Setorial do Centro de Teologia e Ciências Humanas - PUC-Rio

Rio de Janeiro, 10 de abril de 2013. 
Todos os direitos reservados. É proibida a reprodução total ou parcial do trabalho sem autorização da universidade, da autora e da orientadora.

Deise de Lacerda Paiva

Graduou-se em Letras (Português e respectivas literaturas) na UERJ em 2008. Tem especial interesse em pesquisas que se situem na interface entre tecnologia e linguagem.

Ficha Catalográfica

Paiva, Deise de Lacerda

A interação tutor-aluno no ambiente de educação à distância: um estudo de caso / Deise de Lacerda Paiva ; orientador: Maria do Carmo Leite de Oliveira. $-2013$.

95 f. : il. (color.) ; $30 \mathrm{~cm}$

Dissertação (mestrado)-Pontifícia Universidade Católica do Rio de Janeiro, Departamento de Letras, 2013.

Inclui bibliografia

1. Letras - Teses. 2. Educação a distância. 3. Interação tecnologizada. 4. Tutor-aluno. I. Oliveira, Maria do Carmo Leite de. II. Pontifícia Universidade Católica do Rio de Janeiro. Departamento de Letras. III. Título.

CDD: 400 
Para meus pais, José Carlos e Maria Isabel, meus exemplos de caráter e de integridade. 


\section{Agradecimentos}

A Deus, Pai amoroso, pelo sustento e pelo cuidado.

A minha orientadora, Prof. ${ }^{\text {a }}$ Maria do Carmo, pelos ensinamentos que ultrapassaram (e muito) a esfera acadêmica, pela convivência nestes últimos anos, que foi, para mim, o maior presente.

A minha irmã, Carla, pelas palavras de incentivo a cada dificuldade, pela compreensão, por ser sempre meu porto seguro.

A minha família, Igor, Isabelle, Wander e Fabrícia, pela compreensão pela constante ausência nestes últimos meses.

A Pontifícia Universidade Católica do Rio de Janeiro, pela bolsa de estudos, sem a qual este trabalho não poderia ter sido realizado.

Aos meus professores $\mathrm{M}^{\mathrm{a}}$ das Graças Pereira, Liliana Cabral, Violeta Quental e Maria Paula Frota, pela grande contribuição na minha formação acadêmica.

A Chiquinha, Secretária da Pós-Graduação, por sua atenção e boa vontade incondicionais.

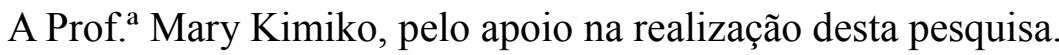

Aos meus amigos Aline Milani, Catia Barbosa, Ana Bárbara Vale, Maristela Rivera, Fernanda e Felipe Barcellos, André Ribeiro e Vinicius Lessa, pela ajuda de tantas formas, em diferentes momentos, nestes últimos três anos.

Aos amigos da Primeira Igreja Batista em Copacabana, pelo cuidado e pelas orações. 
Ao Prof. Mariano Pimentel, do Departamento de Informática da UniRio, por despertar em mim a paixão pela pesquisa, cujas aulas jamais serão esquecidas.

A Maria Alice Mendes e Flávia Oliveira, pelos sábios conselhos de quem já trilhou por este caminho.

Aos meus colegas de equipe, pela compreensão e pelo apoio nos momentos difíceis. 


\section{Resumo}

Paiva, Deise de Lacerda; Oliveira, Maria do Carmo Leite de. A interação tutor-aluno no ambiente de Educação a Distância: um estudo de caso. Rio de Janeiro, 2013. 95p. Dissertação de Mestrado - Departamento de Letras, Pontifícia Universidade Católica do Rio de Janeiro.

O avanço das tecnologias para a comunicação favoreceu a transposição da aula presencial para o ambiente virtual, criando facilidades de acesso à educação. Um desafio da educação a distância é o de encontrar estratégias que tornem os alunos autônomos e coconstrutores do conhecimento. Neste trabalho, buscamos examinar como a gestão das possibilidades da tecnologia pode contribuir ou não para o alcance desse objetivo. À luz de uma abordagem sociointeracional, analisamos a interação tutor-aluno num curso oferecido a profissionais da área pública. Os resultados apontam para a influência da mediação tecnológica no desempenho dos papéis atribuídos ao tutor, a manutenção de um modelo de gerenciamento da interação, centrado no professor e sem a troca entre colegas.

\section{Palavras-chave}

Educação a distância; interação tecnologizada; tutor-aluno. 


\section{Abstract}

Paiva, Deise de Lacerda; Oliveira, Maria do Carmo Leite de (Advisor). Tutor-student interaction in the Distance Learning environment: a case study. Rio de Janeiro, 2013. 95p. MSc. Dissertation - Departamento de Letras, Pontifícia Universidade Católica do Rio de Janeiro.

The advance of communication technologies has favored the change from classroom learning to the virtual environment, creating facilities for the access to education. One of the challenges of distance learning is to find strategies which can turn students into autonomous co-constructors of knowledge. In this paper we examine how the management of technology can contribute - or not - to the accomplishment of this goal. From a socio-interactive perspective, we analyzed the tutor-student interaction in a course given to professionals from the public sector. The results point to the influence of technological mediation in the roles attributed to the tutor, the maintenance of an interaction management model, centered on the teacher and without interchange among classmates.

\section{Keywords}

Distance learning; technologized interaction; tutor-student. 


\section{Sumário}

1. Introdução 12

2. A Educação a Distância: história e proposta 16

2.1. As três gerações da EAD 16

2.2. A EAD no Brasil 18

2.3. A proposta da EAD 22

3. Interação: pressupostos teóricos 28

3.1. Interação e tecnologia 28

3.2. Interação: atividade e papéis $\quad 29$

3.3. A fala-em-interação 33

4. Metodologia da pesquisa 39

4.1. Objetivo da pesquisa 39

4.2. Caracterização da pesquisa 40

4.3. Contexto da pesquisa 41

4.4. Geração e análise de dados 42

5. Os papéis da atividade do tutor na sala de aula virtual 46

5.1. Os papéis do tutor na área pedagógica, técnica e social 46

5.2. Os papéis da atividade 50

5.2.1. O papel de orquestrador $\quad 50$

5.2.2. Papel de mediador $\quad 59$

5.2.3 O papel de animador/motivador 62

6. Organização da troca interacional e o modelo pedagógico 66

6.1. Padrão 1 - Troca centrada no tutor 66

6.2. Padrão 2 - Troca centrada no aluno 84 
7. Considerações finais

Referências bibliográficas 


\section{Lista de tabelas}

Tabela 1 - Marcos da Educação a Distância no Brasil 19

Tabela 2 - Número de participações em sala de aula 


\section{Introdução}

"Educação a distância", "ensino a distância", "ensino on-line", "educação mediada por computador", "e-learning" são alguns dos termos utilizados para designar uma prática pedagógica não presencial.

Apesar do dissenso sobre o rótulo, há um consenso no modo como se entende atualmente Educação a Distância - doravante EAD:

Educação a distância é o aprendizado planejado que ocorre normalmente em um lugar diferente do local de ensino, exigindo técnicas especiais de criação do curso e de instrução, comunicação por meio de várias tecnologias e disposições organizacionais e administrativas especiais. (MOORE; KEARSLEY, 2007, p. 2)

(é) uma forma de ensino que possibilita a autoaprendizagem, com a mediação de recursos didáticos sistematicamente organizados, apresentados em diferentes suportes de informação, utilizados isoladamente ou combinados, e veiculados pelos diversos meios de comunicação." (Lei de Diretrizes e Bases $n^{\circ}$ 9.394, de 20 de dezembro de 1996)

Como mostram ambas as definições, a proposta de uma nova modalidade de ensino/aprendizagem vem ancorada no uso da tecnologia. É ela que oferece condições para uma maior flexibilidade no que diz respeito ao tempo e espaço de aprendizagem; que favorece o desenvolvimento da autonomia do aluno, a construção coletiva do conhecimento, na medida em que, ao se apropriar de diferentes mídias, possibilita novos arranjos interacionais para o cenário da sala de aula, o que envolve novos papéis para o professor.

De fato são inegáveis as possibilidades que a tecnologia oferece para uma revolução nos métodos de ensino/aprendizagem. O avanço das tecnologias de comunicação e informação vem continuamente renovando as práticas pedagógicas. No Brasil, em especial, o incremento das novas mídias, aliado a políticas públicas orientadas pela busca de maior acesso à educação, explica o salto da EAD nos últimos anos.

Mas, até que ponto a $\mathrm{EAD}$, com todos os recursos tecnológicos, conseguiu criar um ambiente em que o tutor assume o papel de facilitador do conhecimento e em que as trocas conversacionais mostram que o aluno participa da construção desse conhecimento? 
Interessa-nos aqui examinar como tutor e aluno de um curso a distância gerenciam as possibilidades da tecnologia para a construção desse novo ambiente de aprendizagem.

Para atingir esse objetivo maior, estabelecemos os seguintes objetivos intermediários:

i) Identificar os papéis de atividade e os papéis discursivos que emergem no modo como o tutor interage na sala de aula virtual;

ii) Identificar que modelo pedagógico subjaz à organização das trocas interacionais no cenário virtual.

A proposta desta pesquisa se insere na área da Linguística Aplicada (LA) com interesse em práticas profissionais. Entendemos que pesquisas em EAD podem contribuir na formação de profissionais da área, uma vez que ela envolve desafios que implicam na aquisição de novas competências e de uma forte habilidade interacional. Além disso, a literatura que estuda a complexidade do processo interacional em cursos de EAD ainda é incipiente - embora vasta, versando sobre os papéis do tutor é, em grande parte, apenas prescritiva (TAVARES, 2005, p.87). Alguns artigos, inclusive, apontam para ausência de pesquisas que investiguem os papéis desse profissional na prática social. Dentre eles, podemos citar o artigo de TAVARES (2005), como ponto de partida para a presente pesquisa. Nesse trabalho, a autora faz uma revisão da literatura da área e destaca que a mesma em sua grande parte se limita a: (i) prescrever papéis e tarefas para o tutor; (ii) privilegiar a investigação da prática individual desse profissional ou mesmo a partir de sua própria percepção de atuação por meio de entrevistas e questionários.

Em termos teóricos, o estudo sobre interação tecnologizada se apoia na visão de Hutchby (2001) de que os artefatos tecnológicos oferecem um leque determinado de possibilidades e restrições, mas não determina o que as pessoas fazem com esses artefatos. No que diz respeito aos papéis de atividade e papéis discursivos, ancoramos a análise no trabalho de Merton (1968), (Levinson, 1979) e Sarangi $(2010,2011)$. Quanto às trocas interacionais, recorremos às contribuições de Harvey Sacks, Emanuel A. Schegloff e Gail Jefferson (2003[1974]) e Garcez (2006, 2008), uma vez que a descrição do comportamento verbal em conversas espontâneas é a matriz para outras modalidades da conversa. 
O corpus de análise se constitui das mensagens trocadas entre a tutora e alunos em uma sala de aula virtual (um fórum eletrônico) de uma das disciplinas de um curso de pós-graduação oferecido por uma universidade carioca a uma turma composta em sua maioria por servidores públicos de diferentes estados do país.

Este trabalho é composto por seis capítulos: (1) A Educação a Distância: história e proposta; (2) Pressupostos teóricos relativos à interação; (3) Metodologia; (4) Os papéis do tutor em sala de aula; (5) Organização da troca interacional e modelo pedagógico; (6) Considerações finais.

O primeiro capítulo inicia com um breve resumo da história da EAD, desde o surgimento dos cursos por correspondência, passando pela utilização dos meios de comunicação em massa, como o rádio e a $\mathrm{TV}$, até a introdução de computadores e da internet na EAD (FREITAS, 2009).

Apresenta um panorama da EAD no Brasil (VIANNEY et al, 2003), mostrando os fatores que contribuíram para sua expansão e alguns dados relacionados ao crescimento dessa modalidade no país (INFO, 2012), (CENSO.EAD. BR, 2012).

Neste primeiro capítulo, apresentamos ainda a proposta atual da EAD e suas principais correntes teóricas (MOORE; KEARSLEY, 2007), e os papéis apontados pela literatura para o tutor (MOORE; KEARSLEY, 2007), (BENTES, 2009) (LÉVY, 2008), (MAIA; MATTAR, 2007), (BERGE, 1995), (TAVARES, 2005).

Essa abordagem inicial tem como objetivo apresentar o contexto atual da EAD, destacando a importância dada à interação no processo de aprendizagem com a evolução das novas tecnologias.

O segundo capítulo, por sua vez, traz os pressupostos teóricos relativos à interação. Iniciamos focalizando a relação interação/tecnologia a partir dos estudos de HUTCHBY (2001); a seguir, os conceitos de papel e de atividade (MERTON, 1968), (LEVINSON, 1979), SARANGI $(2010,2011)$ e; finalmente, os conceitos relevantes para a análise no que diz respeito à organização da conversa (SACKS, SCHEGLOFF; JEFFERSON, 2003[1974]), (GARCEZ, 2006, 2008). 
O quarto capítulo trata do referencial metodológico adotado no presente estudo, que se insere na perspectiva qualitativa, utilizando o estudo de caso como método de pesquisa.

O quinto capítulo contém as análises das mensagens trocadas entre a tutora e os alunos em sala de aula. São observados, principalmente, os papéis desempenhados pelo tutor e a organização da troca interacional.

Por fim, o sexto capítulo apresenta as considerações finais, que apontam para as dificuldades enfrentas pelos participantes - tutora e alunos - em gerenciarem as possibilidades da tecnologia para a criação de um novo ambiente de aprendizagem. 
2

A Educação a Distância: história e proposta

Neste capítulo, trazemos uma breve apresentação da história da EAD no cenário mundial e brasileiro. Incluímos ainda uma breve revisão da literatura sobre EAD, destacando algumas das questões relevantes na caracterização de sua proposta.

\section{1}

\section{As três gerações da EAD}

A história da EAD, no cenário mundial, tem sido contada a partir da identificação de três gerações, no que se refere aos tipos de canais utilizados.

- A primeira geração: os cursos por correspondência e via rádio

Não existe um consenso sobre o evento que inaugura a educação a distância (FREITAS, 2009, p. 39). Acredita-se que o primeiro registro sobre cursos por correspondência date de 1728. Nesse ano, um anúncio foi veiculado em um jornal de Boston sobre aulas ministradas por Caleb Phillip. As lições do "curso" eram enviadas, semanalmente, aos alunos inscritos pelo correio.

Experiências isoladas também foram desenvolvidas em outros países, no mesmo período. Em 1840, na Grã-Bretanha, Isaac Pitman ofereceu um curso de taquigrafia e, em 1880, o Skerry's College Lynch Correspondence Tuition Service, cursos de contabilidade.

Nos meados do século XIX, as universidades de Cambridge e Oxford, por sua vez, começaram a ministrar cursos nesse formato; logo após, as universidades de Chicago e Wisconsin, nos Estados Unidos, seguiram pelo mesmo caminho.

Duas outras escolas por correspondência marcam a primeira geração. Uma delas foi a Escola Alemã de Negócios, criada em 1924. A outra foi a Queensland, criada em 1910, na Austrália. 
Em 1928, a BBC de Londres inova, desenvolvendo, dessa vez, cursos via rádio, tecnologia esta que veio a ser replicada posteriormente em vários países, inclusive no Brasil, a partir da década de 1930, como veremos.

No início do século XX, houve um grande desenvolvimento do ensino por correspondência. Durante a Segunda Guerra, a necessidade de capacitação dos recrutas levou ao aparecimento de novos métodos, inclusive para o ensino do Código Morse, amplamente utilizado durante o conflito. Posteriormente, nos tempos de paz, esses métodos foram reaproveitados para ensinar a população no período de reconstrução da Europa.

\section{- A segunda geração: os cursos via TV e as universidades abertas}

Em meados dos anos 1960, houve uma grande expansão da educação secundária e superior na Europa, principalmente na França e Inglaterra. A partir dessa época, a televisão começou a ser utilizada como meio educacional. Entre as décadas de 1960 e 1980, temos a consolidação da televisão educativa, que evolui e se articula com outros meios de comunicação. Acreditava-se que a televisão poderia imprimir um novo ritmo ao ensino devido à extensão de seu alcance.

Nesse contexto, surge a primeira universidade a distância, a British Open University, na Inglaterra: "pela primeira vez, se obteve uma maior visibilidade em relação à possibilidade de se oferecer um ensino a distância percebido como de qualidade e equivalente ao modelo tradicional presencial" (FREITAS, 2009, p. 40). Outras universidades surgiram posteriormente à criação da Open. Atualmente, essas instituições possuem sede em vários países do mundo. Por causa do enorme quantitativo de seus alunos (chegando a mais de 200 mil, como no caso da Open), são usualmente conhecidas como megauniversidades abertas a distância.

Cabe ressaltar que, no período de surgimento das universidades abertas, as universidades tradicionais não tiveram interesse em oferecer cursos a distância, pois consideravam altos os custos para desenvolver programas de qualidade, além de não acreditarem na qualidade de tal modalidade de ensino (FREITAS, 2009, p. 41). 
- A terceira geração: os cursos via novas mídias e internet

Se as gerações passadas se caracterizaram pelo uso do correio, do rádio e da televisão, a terceira geração será predominantemente marcada pela utilização do computador e, posteriormente, da internet.

À época de seu surgimento, os computadores só foram utilizados para fins educacionais nas universidades por causa de seu custo oneroso. A partir da década de 1990, com o surgimento dos computadores pessoais e o amplo desenvolvimento da internet, esse cenário se modificou.

A internet foi responsável por uma fase totalmente nova e revolucionária da EAD, principalmente por causa das mudanças na transmissão e veiculação de informações. Com advento da rede mundial de computadores, foi possível estabelecer diferentes tipos de comunicação: (i) a síncrona em que os participantes compartilham o mesmo tempo de produção e recepção; (ii) a assíncrona em que eles estão deslocados no tempo, o que veio ampliando de forma extraordinária as possibilidades de interação.

\section{2}

\section{A EAD no Brasil}

\section{- Sua história}

Por volta de 1900, anúncios de cursos profissionalizantes de datilografia já eram veiculados no Brasil. Porém, o marco oficial no país data de 1904, com a instalação das Escolas Internacionais. Essas escolas eram filiais de uma organização americana, voltadas para pessoas à procura de emprego, especialmente na área do comércio e serviços. O ensino era ministrado por correspondência, e os materiais eram enviados pelo correio.

Em 1925, é fundada a Rádio Sociedade do Rio de Janeiro, cujo objetivo era a educação popular. A partir dessa época, os programas educativos via rádio se multiplicaram em todo mundo. Na década de 1950, surgem as escolas radiofônicas que passam a oferecer diversos cursos do Norte ao Sul do país.

Nas décadas de 1960 e 1970, a televisão passa a ter fins educativos. Com a publicação do Código Brasileiro de Telecomunicações, estabelece-se a 
determinação de programas com fins educacionais no rádio e na televisão. Em 1969, cria-se o Sistema Avançado, e o Ministério das Comunicações define um tempo obrigatório a ser cedido a programas educativos por todas as emissoras.

Em 1994, há uma reformulação do sistema, e a Fundação Roquete Pinto passa a estar à frente dessas ações. Poucos avanços na área ocorrem nessa época, e os horários estabelecidos para os programas educativos se mostram incompatíveis com a disponibilidade do público-alvo. Dessa época, cabe destacar a qualidade dos programas desenvolvidos pela Fundação Roberto Marinho e pela TV Escola, esta última com atuação limitada por depender da veiculação de seus programas em emissoras abertas e canais a cabo.

Podem-se resumir os principais eventos de destaque da EAD no Brasil de acordo com os seguintes marcos (VIANNEY et al, 2003, p. 37, 38).

\begin{tabular}{|c|c|}
\hline 1904 & Mídia impressa e correio - ensino por correspondência privado. \\
\hline 1923 & Rádio Educativo Comunitário. \\
\hline 1923-1941 & $\begin{array}{l}\text { Instituto Monitor e Instituto Universal Brasileiro }- \text { cursos } \\
\text { profissionalizantes por correspondência. }\end{array}$ \\
\hline $1965-1970$ & Criação das TVs Educativas pelo poder público. \\
\hline 1980 & $\begin{array}{l}\text { Oferta de supletivos via telecursos (televisão e materiais impressos), } \\
\text { por fundações sem fins lucrativos. }\end{array}$ \\
\hline 1985 & Uso do computador stand alone ou em rede local nas universidades. \\
\hline 1985-1998 & $\begin{array}{l}\text { Uso de mídias de armazenamento (videoaulas, disquetes, CD-ROM, } \\
\text { etc.) como meio complementares. }\end{array}$ \\
\hline 1989 & Criação da rede nacional de pesquisa (uso de BBS, Bitnet e e-mail). \\
\hline 1990 & $\begin{array}{l}\text { Uso intensivo de teleconferências (cursos via satélite) em programas } \\
\text { de capacitação a distância. }\end{array}$ \\
\hline 1994 & Início da oferta de cursos superiores a distância por mídia impressa. \\
\hline 1995 & $\begin{array}{l}\text { Disseminação da internet nas Instituições de Ensino Superior via } \\
\text { RNP. }\end{array}$ \\
\hline 1996 & $\begin{array}{l}\text { Redes de videoconferência - Início da oferta de mestrado a distância, } \\
\text { por universidade pública em parceria com empresa privada. }\end{array}$ \\
\hline 1997 & $\begin{array}{l}\text { Criação de ambientes virtuais de aprendizagem. Início da oferta de } \\
\text { especialização a distância, via internet, em universidades públicas e } \\
\text { particulares. }\end{array}$ \\
\hline $1999-2001$ & $\begin{array}{l}\text { Criação de redes públicas, privadas e confessionais para cooperação } \\
\text { em tecnologia e metodologia para o uso das NTICs na EAD. }\end{array}$ \\
\hline 1999-2002 & $\begin{array}{l}\text { Credenciamento oficial de instituições universitárias para atuar em } \\
\text { educação a distância. }\end{array}$ \\
\hline
\end{tabular}

Tabela 1 (Marcos da Educação a Distância no Brasil) 
No Brasil, a expansão da internet bem como criação de leis que regulasse o funcionamento da EAD implicaram grandes mudanças nessa modalidade, cujos números serão apresentados na próxima seção.

\section{- Seus números}

Em seus primórdios, a EAD no país contava com um status de menor prestígio. À época, eram oferecidos cursos livres profissionalizantes pouco conceituados e destinados àqueles que não tinham acesso à educação formal.

Esse cenário só se modificou a partir de constantes mudanças nas leis que regulavam a educação no país. Podemos observar que, pouco a pouco, de decreto em decreto, a legislação educacional abriu espaço para essa modalidade. Porém, apenas em 1996, com a Segunda Lei de Diretrizes e Bases, torna oficial a EAD no país. Dois anos depois, em 1998, temos, finalmente, a sua normatização. Em 2001, uma portaria do Ministério da Educação permitiu a oferta de disciplinas a distância com equivalência de até $20 \%$ da carga horária em cursos reconhecidos. Hoje, depois de diversos avanços na área, a certificação dos cursos a distância já equivale aos da modalidade presencial.

Além dessa evolução na legislação brasileira, o desenvolvimento das Tecnologias da Informação e da Comunicação (TICs) e o crescimento da internet também contribuíram para o salto dado pela EAD no país. De acordo com o Ibope Media, o Brasil é considerado quinto país mais conectado, com 94,2 milhões de internautas (INFO, 2012). O principal local de acesso à internet é a lan house (31\%), seguido da própria casa $(27 \%)$ e da casa de parente de amigos, com $25 \%$. O Brasil é ainda o quinto país com o maior número de conexões à Internet (INFO, 2012). Segundo dados divulgados recentemente pelo instituto, "50,7 milhões de usuários acessam regularmente a Internet. 38\% das pessoas acessam a web diariamente; $10 \%$ de quatro a seis vezes por semana; $21 \%$ de duas a três vezes por semana; $18 \%$ uma vez por semana. Somando, $87 \%$ dos internautas brasileiros entram na internet semanalmente" (INFO, 2012).

A Associação Brasileira de Educação a Distância (ABED), por sua vez, vem realizando ao longo de alguns anos um censo com intuito de retratar a atual configuração da EAD no país. Os resultados do censo realizado em 2010 mostram 
dados distintos e relevantes. Essas informações são fruto de pesquisas realizadas com instituições credenciadas educacionais, empresas fornecedoras de produtos e serviços, e professores independentes de vínculos institucionais que desenvolveram atividades de EAD no país, no ano de 2010. Na ocasião, foram convidadas a participar, por e-mail, 812 instituições. No site da ABED, também estava disponível um informe convidando interessados para participarem do Censo independentemente do convite. Desse universo, 198 instituições responderam ao questionário.

Os dados levantados incluem: quais cursos são oferecidos por quais instituições de ensino, qual é o número de matrículas, quais os recursos utilizados por essas instituições, as mídias, qual o perfil de seus alunos, dentre outras informações. Mostram também quais empresas adotam essa modalidade de ensino para capacitar seus funcionários, os resultados obtidos, os investimentos (já utilizados e previstos) e a avaliação das próprias instituições sobre os serviços prestados.

Esses resultados dão conta do enorme universo da EAD hoje no Brasil, a começar pelo aumento no número de matrículas nos últimos três anos que já ultrapassa a marca de dois milhões de alunos (CENSO EAD.BR, 2012, p. 8), tendo crescido mais de $100 \%$ em relação ao anterior, 2009. A maior parte das matrículas se concentra nos cursos corporativos, 38\% (CENSO EAD.BR, 2012, p. 11).

As previsões apontam que esse contingente pode mudar em breve, pois há grandes perspectivas de crescimento na área, já que os investimentos de instituições educacionais na área têm crescido exponencialmente, tendo os cursos autorizados crescido em mais de 40\%, no período de 2008-2010. (CENSO EAD.BR, 2012, p. 12).

Além do maior número de matrículas, os cursos corporativos também contam com o maior percentual de crescimento em investimentos, seja na ampliação das ofertas já existentes (CENSO EAD.BR, 2012, p. 12).

Segundo o censo, os alunos veem na escolha de um curso a distância a oportunidade de requalificação, com a utilização das ferramentas da TICS já comuns ao seu dia a dia, com a flexibilidade de espaço e tempo.

Outro ponto relevante é a crescente utilização de cursos a distância pelas empresas para capacitação de seus colaboradores. Diante de um mercado 
altamente competitivo como o atual, as empresas veem vantagens em capacitar seus colaboradores por meio da EAD. De acordo com as empresas entrevistadas, algumas dessas vantagens são, entre outras: redução de custos, a agilidade na realização, a flexibilidade e adoção de modelo pedagógico próprio.

Além disso, segundo o censo, cabe destacar que, se antes a preocupação das instituições que trabalham com EAD se relacionava com a qualidade do conteúdo e do material didático oferecido, hoje elas consideram fundamental o acompanhamento e apoio pedagógico ao aluno por um profissional.

Visto como alguém que pode reduzir a evasão dos cursos, o tutor nomenclatura mais utilizada (CENSO EAD.BR, 2012, p. 46) - se faz presente em grande parte dos cursos oferecidos no mercado (CENSO EAD.BR, 2012, p. 46), embora não haja também ainda um consenso sobre seus papéis (CENSO EAD.BR, 2012, p. 45).

No presente trabalho, adotamos o termo "tutor" para nos referir a esse profissional, já que esta é a nomenclatura utilizada pela instituição cujos dados serviram de base para a pesquisa, e buscamos, por meio da análise da interação, identificar seus papéis.

\section{3}

\section{A proposta da EAD}

Segundo Moore e Kearsley, a educação a distância é:

o aprendizado planejado que ocorre normalmente em lugar diferente do local de ensino, exigindo técnicas especiais de criação do curso e de instrução, comunicação por meio de tecnologias e disposições organizacionais e administrativas especiais (MOORE; KEARSLEY, 2007, p. 2)

Dentre as características apontadas por esses dois teóricos, cabe destacar três delas que estão diretamente relacionadas a essa modalidade de educação. A primeira é o aprendizado planejado. Ainda que aprendamos de diversas formas possíveis, o aprendizado na EAD não ocorre por acaso, não é apenas a percepção de algo ainda desconhecido, mas deve ser entendido como processo que requer planejamento. Nesse caso, o aluno se propõe a aprender, e o professor conta com alguns meios para auxiliar no suporte ou apoio do aprendizado desse aluno. Outra 
característica própria da EAD é a separação de local (e, por vezes, de tempo também) entre ensino e aprendizado, ou seja, isso pressupõe que professores e aluno estejam separados, pelo menos, em termos de localidade. Nem sempre programas que se dizem a distância, na verdade, o são. Por exemplo, o termo $e$ learning que, por vezes, é utilizado como sinônimo para $\mathrm{EAD}$, não precisa ser oferecido necessariamente a distância, podendo ser adotado de forma presencial, porque pressupõe apenas a utilização de tecnologias digitais no processo do ensino-aprendizado. Por fim, vale destacar que a comunicação na EAD se realiza por meio de tecnologias como meio único ou principal (MOORE; KEARSLEY, 2007 ,

p. 2-3).

\section{- Principais correntes teóricas}

Apesar de a origem da educação a distância datar de meados do século XIX, uma teoria geral da pedagogia da EAD surgiu apenas na década de 1960.

\section{A teoria de Otto Peters}

A primeira teoria de educação a distância conhecida foi desenvolvida por Otto Petters. Tendo sido concebida como uma teoria organizacional, preconizava a "aplicação de técnicas industriais na transmissão e instrução". Essas técnicas, evidentemente, acabavam por encarecer o custo da educação que, segundo ele, poderia ser amortizado pelo oferecimento em grande escala. Seu modelo sofreu críticas na época, pois já trazia a ideia da educação em larga escala e massificada, não respeitando o ritmo individual de aprendizagem (MOORE; KEARSLEY, 2007, p. 238-239).

\section{A teoria pedagógica de Charles Wedemeyer}

Diferentemente de Peters, a teoria de Wedemeyer, com um foco pedagógico foi a primeira grande contribuição reconhecida na área da EAD. Wedemeyer defendia o aluno "como uma pessoa não independente no espaço e no 
tempo, mas também potencialmente independente no controle e no direcionamento do aprendizado" (MOORE; KEARSLEY, 2007, p. 239).

Seu pensamento teve tanto influência na época, que ele foi convidado para participar do planejamento e da implantação da Open University britânica, reconhecidamente a maior universidade aberta até os dias atuais.

\section{A Teoria da Distância Transacional de Michael Moore}

Apesar de trabalhar diretamente com Wedemeyer, Moore identificou algumas limitações em sua proposta de estudo independente (FREITAS, 2009, p. 46), tendo desenvolvido então uma teoria com uma perspectiva mais centrada no aluno e em sua interação com o professor, que ficou conhecida com a Teoria da Distância Transacional (MOORE; KEARSLEY, 2007, p. 239).

Segundo essa teoria:

à distância transacional não interessa a distância física entre professor e aluno, ou mesmo entre os alunos, mas sim as relações pedagógicas e psicológicas que se estabelecem na EAD. Portanto, independentemente da distância espacial ou temporal, os professores e os alunos podem estar mais ou menos distantes em EAD, do ponto de vista transacional. (MAIA; MATTAR, 2007, p. 14)

O efeito que a distância geográfica exerce é relativo. Sendo considerado relativo, este recairia sobre duas variáveis: a estrutura e o diálogo, que estão relacionadas à autonomia do aluno (MOORE; KEARSLEY, 2007, p. 241). Tal teoria teve tamanho alcance que teorias subsequentes surgiram com maior enfoque na interação, no relacionamento entre professores e alunos.

\section{A teoria da Conversação Didática}

Borje Holmberg entendia como premissa para a educação o desenvolvimento do diálogo com o aluno. Segundo ele, "a boa educação a distância" implica em uma "conversação dirigida com o objetivo do aprendizado", na "presença de aspectos típicos de uma conversação que facilite o aprendizado", por isso é imprescindível a utilização de "materiais de autoinstrução bem preparados e uma comunicação a distância interativa e adequada" (MOORE; KEARSLEY, 2007, p. 239). 


\section{O modelo de controle de Garrison}

Garrison propõe uma mudança de paradigma ao desenvolver um modelo diferente das teorias de até então (modelo industrial de Peters ou do estudo independente de Wedemeyer).

Para ele, "a transação ensino-aprendizado" se apresenta como "ponto fundamental da prática da educação a distância”. Segundo ele:

o controle é definido como uma oportunidade e uma habilidade de influenciar o processo (ou transação) educacional. A comunicação em duas vias se torna central à medida que se pode controlar o grau de liberdade e independência dos participantes, diminuindo assim, o risco de sentirem isolados no processo de aprendizagem (FREITAS, 2009, p. 52).

Com o avanço das TICs percebe-se que ocorreu uma reformulação das teorias levando em conta o caráter social da aprendizagem (FREITAS, 2009, p. 46).

\section{- Papéis do tutor}

Nesta subseção, tratamos dos papéis do tutor dando enfoque naqueles que são mais representativos na literatura de EAD. Sendo assim, não temos como objetivo esgotar esse assunto nem fazer uma revisão de literatura a respeito neste momento. Posteriormente, trataremos dos papéis que emergem na interação, e estes sim se enquadram dentro do escopo deste trabalho.

Existem várias terminologias para denominar o profissional responsável pelo apoio ao aluno no ambiente virtual: mediador, professor, tutor, entre outros. O termo mediador é, frequentemente, atribuído ao responsável pela interação entre os participantes em fóruns eletrônicos, podendo exercer a figura de uma espécie de censor das mensagens publicadas. Muitos programas preferem usar essa denominação quando esse profissional não se trata exatamente de um especialista na área em que atua e, na verdade, é apenas responsável por "incentivar" a participação dos alunos. O professor, por sua vez, nos remete ao profissional do modelo convencional que, por vezes, pode atuar como tutor, sendo 
o menos utilizado nesse contexto. O termo mais difundido é mesmo o de tutor, que é visto como um facilitador da aprendizagem. Neste trabalho, utilizaremos “tutor”, pois esta é a nomenclatura adotada pelo programa analisado.

A atividade do tutor está relacionada a diferentes tarefas ou responsabilidades que são atribuídas a esse profissional. Nesse sentindo, a literatura da EAD apresenta diferentes visões.

Uma função do tutor é "ajudar os alunos a aprender o conteúdo do curso" por meio da interação, proporcionado "uma instrução individualizada com base nos materiais elaborados" (MOORE; KEARSLEY, 2007, p. 17).

Ampliando essa visão, defende-se ainda que esse profissional não deve apenas auxiliar na aprendizagem, mas é “o agente motivador/orientador que irá acompanhar e avaliar o aprendizado do aluno durante todo o processo". Diante disso, o tutor tem de assumir algumas competências que são inerentes ao desempenho dessa função: "saber lidar com os ritmos individuais diferentes de cada aluno, apropriar-se de novas TICs, dominar as técnicas e instrumentos de avaliação, ter habilidades de investigação, utilizar novos esquemas mentais para criar uma nova cultura indagadora e plena em procedimentos de criatividade e ter disponibilidade para intervir a qualquer momento" (BENTES, 2009, p. 166-167).

Segundo Lévy, diante dos recentes avanços das TICs, a atividade desse profissional:

não pode ser mais uma difusão de conhecimentos, que agora é feita de forma mais eficaz por outros meios. Sua competência deve deslocar-se no sentido de incentivar a aprendizagem e o pensamento. O professor tornar-se um animador da inteligência coletiva dos grupos que estão a seu encargo. Sua atividade será centrada no acompanhamento e na gestão das aprendizagens: o incitamento à troca dos saberes, a mediação relacional e simbólica, a pilotagem personalizada dos percursos de aprendizagem etc. $(2008, \text { p. } 171)^{1}$

Desviando-se um pouco dessas propostas anteriores cujo foco está nas competências, defende-se uma série de ações próprias da tutoria on-line: "organizar a classe virtual, definindo o calendário e os objetivos do curso"; responsabilizar-se pelo "contato inicial com a turma", por "provocar a apresentação dos alunos", por "fornecer feedback rápido", por "gerar um senso de comunidade"; "elaborar atividades, incentivar a pesquisa", fazer perguntas, avaliar

1 Pierre Lévy denomina professor, não fazendo diferenciação de sua atuação presencial ou virtualmente. 
respostas, relacionar comentários", entre outras tarefas (MAIA; MATTAR, 2007, p. 91).

A tutoria on-line estaria atrelada então a várias atividades que podem ser agrupadas em quatro áreas: pedagógica, social, gerencial e técnica. A área pedagógica está atrelada ao papel moderador como facilitador educacional; a área social refere-se à criação de um ambiente amigável centrado nas relações humanas e na valorização das contribuições; a gerencial corresponde a administrar o calendário e as tarefas junto à turma e; por fim, a área técnica, em dar suporte aos alunos quanto à dúvida e às dificuldades relacionadas à tecnologia (BERGE, 1995).

Em virtude de o programa analisado relacionar a tutoria on-line a uma lista de atividades como, por exemplo, abrir discussões dos módulos, elaborar questões que favoreçam o debate, publicar o calendário, passar procedimentos, entre outras, adotamos para esta pesquisa uma visão centrada nas ações a serem desenvolvidas por esse profissional ao longo do curso e não nas competências.

No artigo que serviu como ponto de partida para esta pesquisa, Tavares realiza uma vasta revisão de literatura sobre os papéis do tutor e conclui que: (1) grande parte da literatura apenas prescreve ações desse profissional, (2) outra parte, por sua vez, descreve essas ações, (3) e uma terceira investiga essa prática a partir da própria perspectiva desse profissional por meio de entrevista e questionários. Segundo ela, "faltam pesquisas que priorizem a contextualizações das ações e percepções do moderador no âmbito da prática social, da atividade coletiva de discussão e/ou aprendizagem colaborativa em que o trabalho de moderação está inserido" (2005, p. 88).

Neste trabalho, temos como objetivo investigar os papéis da atividade do tutor que emergem na interação, o que será apresentado a partir do próximo capítulo. 


\section{3}

\section{Interação: pressupostos teóricos}

O objetivo deste capítulo é apresentar uma revisão bibliográfica, enfocando, principalmente, alguns conceitos relevantes das perspectivas teóricas para a presente pesquisa.

Na seção 3.1, trataremos da relação entre linguagem e tecnologia, na seção 3.2, os principais conceitos da Sociolinguística Interacional; e na seção 3.3, da Análise da Conversa Etnomedotológica.

\section{1}

\section{Interação e tecnologia}

Em um estudo aplicado no contexto de uma central de atendimento (call center), Oliveira e Pereira investigaram a relação entre linguagem e tecnologia (2005, p. 118). Como resultado, verificaram que, embora a interação tecnologizada ofereça possibilidades próprias da tecnologia, ela também cria restrições, como preconiza Hutchby.

Hutchby destaca que hoje há uma multiplicidade de modos em que práticas conversacionais têm interface com dispositivos tecnológicos. Do telefone ao computador, os mais diversos artefatos tecnológicos têm sido utilizados como suporte para comunicação. No entanto, ele enfatiza que esses mesmos suportes não operam sozinhos, são as pessoas que devem gerenciar demandas e restrições que emergem do sistema em suas interações umas com outras (2001, p.1, 2).

A partir do pensamento de Gibson, Hutchby defende uma abordagem baseada no conceito de "affordances". As "affordances" seriam as possibilidades que os artefatos oferecem para a ação (2007, p. 26).

Utilizando como exemplo um ambiente virtual de aprendizagem, podemos observar que, apesar de ampliar o potencial de interação entre as pessoas - que não precisam estar situadas no mesmo local, mas em diferentes cidades ou até mesmo países para se comunicarem, interagirem -, esses ambientes também trazem algumas restrições em termos de trocas interacionais. Isso se comparado a uma sala de aula presencial, já que, por mais que haja dispositivos disponíveis 
para comunicação (como vídeo, áudio, mensagens instantâneas), não existe um contato visual direto, dificultando a visualização de gestos, a percepção da entonação da voz, entre outras pistas, por exemplo.

Por isso, segundo Hutchby, ao examinarmos trocas interacionais mediadas pela tecnologia, temos de levar em conta que os artefatos tecnológicos tanto promovem certas formas de interação entre os participantes como restrigem as possibilidades de outras.

Outro aspecto pertinente é o que preconiza Hutchby sobre utilizar técnicas da Análise da Conversa para examinar como esses artefatos se relacionam às interações interpessoais cotidianas, entendendo a conversa apenas com uma metáfora, mas uma linha de análise para examinar a natureza da relação entre as formas de tecnologia e as estruturas de interação (2001, p. 9). Neste trabalho, utilizamos como abordagem a Análise da Conversa Etnometodológica, cujos conceitos serão abordados a partir da seção 3.3.

\section{2}

\section{Interação: atividade e papéis}

Nesta seção, apresentaremos os principais conceitos da Sociolinguística Interacional, que é uma abordagem em análise de discurso, com uma perspectiva qualitativa, empírica e interpretativa e propõe o estudo da língua na interação social.

Por se tratar de uma abordagem cujos estudos estão centrados na interação, a Sociolinguística se preocupa também com a análise de aspectos extralinguísticos, apresentando um caráter interdisciplinar. Dessa forma, teóricos de outras áreas do conhecimento como a Sociologia, a Psicologia Social, a Antropologia têm contribuído para avanços nos estudos sociolinguísticos em geral. Nesta pesquisa, daremos especial ênfase aos trabalhos de Erving Goffman, Ralph Linton, Robert Merton, Stephen C. Levinson, Srikant Sarangi, entre outros, dada a relevância de alguns conceitos presentes na obra desses pesquisadores para o presente estudo.

Em 1964, em um artigo intitulado "A situação negligenciada", Goffman destaca a importância de se observar um fenômeno que, a seu ver, vem sendo negligenciado até então: a situação social na comunicação face a face (p. 13). Para 
ele, os estudos sociais não deveriam se restringir apenas a trabalhos correlacionais entre variáveis sociais (idade, sexo, etc.) e variáveis linguísticas, ou a estudos indicativos do comportamento linguístico por si só, mas deveriam ir além, utilizando "a situação social como cenário de pesquisa" (2002, p. 13).

Goffman define situação social como "um ambiente que proporciona possibilidades mútuas de monitoramento, qualquer lugar em que um indivíduo se encontra acessível aos sentidos nus de todos os outros que estão presentes e para que os indivíduos são acessíveis de forma semelhante" (2002, p. 17). Em uma situação social, duas ou mais pessoas ratificam "conjuntamente uma(s) à(s) outra(s) como co-sustentadoras autorizadas de um único foco de atenção cognitiva ou visual." (2002, p. 18).

Esses arranjos podem ser os mais variados possíveis como, por exemplo, jogos de cartas, casais em um baile, etc., e é dentro deles que ocorre a fala (2002, p. 18).

Segundo ele, a fala é "socialmente organizada, não apenas em termos de quem fala, mas também como um pequeno sistema de ações face a face, que são mutuamente ratificadas e ritualmente governadas" (2002, p. 19). Duas ou mais pessoas engajadas em um encontro social estão a todo o momento seguindo pistas que regulam suas participações. Essas pistas direcionam quando tomar a palavra, quando cedê-la, e assim por diante.

No entanto, como ele mesmo adverte, a fala não deve ser estudada por si só, pois ainda que a interação tenha seus próprios regulamentos, seus próprios processos e sua própria estrutura, e eles não parecem ser de natureza intrinsicamente linguística, ainda que sejam frequentemente expressos por meio linguísticos (2002, p.14).

Então, a partir da interpretação do que está ocorrendo, da percepção da atividade em andamento, os participantes constroem seu alinhamento em uma dada interação. Isso nos remete ao conceito de tipos de atividade, proposto por Stephen C. Levinson.

Segundo Levinson, a noção de tipos de atividades refere-se "a uma categoria pouco distinta cujos aspectos em foco são acontecimentos com objetivos claros, socialmente estabelecidos e amalgamados, que restringem os participantes, 
o cenário, etc., mas, principalmente as espécies de participações que são permitidas"2 (1979, p. 368).

Levinson ainda destaca a importância do tipo de atividade para o uso da linguagem. Para ele, o tipo de atividade vai determinar qual é contribuição permitida para cada atividade, além de determinar como o que for dito será entendido, ou seja, quais são as possíveis inferências a serem feitas a partir do que é dito (1979, p. 393).

Sarangi, por sua vez, oferece uma releitura da noção de tipos de atividades relacionando com a de papel. Segundo este, se tomarmos uma consulta médica como exemplo, teremos algumas restrições em termos de participação dos interlocutores desta dada interação. Quando o médico pergunta ao paciente “Como você está?", “Como você vai?”, o significado dessas indagações advém do tipo de atividade em que ela está inserida ${ }^{3}$. Desse mesmo modo, essa pergunta pode ser respondida de várias maneiras para (re)definir as relações de papel entre os participantes assim como os limites dos tipos de atividade (SARANGI, 2010, p. 2).

Outro aspecto relevante que diz respeito à relação de tipos de atividades é a categorização. O uso de algumas categorias (no caso da EAD, professor, tutor, mediador, etc.) em detrimento a outras contribuem para definir a situação e a relação entre os papéis.

Sarangi defende que, para qualquer discussão sobre papéis, temos de voltar a Ralph Linton, que equipara o papel social à ocupação social, orientada para as expectativas padrão dos demais: o status como "uma posição em particular que é um conjunto de direitos"; e o papel social como o "aspecto dinâmico de um status que põe em prática os direitos e deveres que formam o status" (SARANGI, 2010, p. 3).

Em sua revisão do modelo de Linton, Robert Merton (1968, p.110), por sua vez, considera o conjunto de papéis como uma teoria para confirmar como o status social se apresenta na estrutura social. Para este, "a teoria de conjunto de

2 "a fuzzy category whose focal members are goal-defined, socially constituted, bounded events with constraints on participants, settings and so on, but above all on the kind of allowable contributions" (Levinson, 1979, p. 368).

3 "The talk format such as 'how are you' derives its meaning from activity type in which it is embedded" (Sarangi,, 2011, p. 2) 
papéis começa com o conceito de que cada status social envolve não um único papel a ele associado, mas um conjunto de papéis" (1968, p. 42). Ainda de acordo com Merton (1968, p. 110):

O status de um professor de escola tem um conjunto de papéis que relaciona o professor não somente ao status correspondente aluno, mas também aos colegas, ao diretor e ao secretário da pasta, ao Comitê Educacional, às associações de classe e, nos Estados Unidos, às organizações patrióticas locais. ${ }^{4}$

Outro aspecto relevante em relação ao desempenho do papel está relacionado ao contexto. O contexto pode mudar, em termos de conjunto de papéis, o desempenho do papel de um dado profissional. Por exemplo, um professor pode ser uma figura de autoridade em sala de aula, mas ocupará um status periférico na reunião de comitê (SARANGI, 2011, p. 9).

No caso da EAD, observamos que a maioria dos programas, por defenderem um ambiente de coconstrução do conhecimento, não atribui ao professor à figura de detentor do conhecimento, propondo certo "esvaziamento" do status desse profissional, o que nem sempre ocorre na prática.

Ainda segundo Sarangi, além das já definidas relações entre papel social relação entre os participantes da interação (mãe-filho, professor-aluno, etc.), papel discursivo (relação entre os participantes e a mensagem - ele/ela estão produzindo, recebendo, transmitindo por outra pessoa, etc.), existe também um papel da atividade que depende do tipo de atividade que o indivíduo está participando e, usualmente, é definido em relação aos outros participantes. Sendo assim, podemos concluir que os papéis podem mudar de acordo com os alinhamentos dos participantes em uma interação ${ }^{5}$. (SARANGI, 2010, p. 39).

4 "[T] he status of school teacher has its distinctive role-set which relates the teacher not only to the correlative status, pupil, but also to colleagues, the school principal and superintendent, the Board of Education, professional associations and, in the United States, local patriotic organisations."

5 While social role refers to the social relationship between the participants (mother-child, teacher-pupil, etc), discourse role refers to the relationship between the participants and the message (is s/he producing it, receiving it, transmitting it on behalf of another, etc.). Activity role is dependent on the activity type the individual is participating in and is usually defined in relation to other participants. 


\section{3}

\section{A fala-em-interação}

Nesta seção, daremos principal ênfase aos principais conceitos da Análise da Conversa Etnometodológica (ACE). A ACE é uma tradição de pesquisa de origem norte-americana, com abordagem sociológica, que tem como objetivo o estudo da ação social humana situada no espaço e no decorrer do tempo real. Seu desenvolvimento se deu a partir da teoria social de Harold Garfinkel, conhecida como Etnometodologia ${ }^{6}$.

Os primeiros estudos desenvolvidos datam de 1960, porém, só a partir de 1970, os analistas da conversa foram reconhecidos dessa forma, com a publicação de seus primeiros trabalhos. Dentre eles, cabe destacar o artigo seminal de Harvey Sacks, Emanuel A. Schegloff e Gail Jefferson (2003[1974]), que apresenta uma descrição da sistemática para a tomada de turno na conversa cotidiana (GARCEZ, 2008, p. 17).

Os primeiros trabalhos sobre a ação humana mediante o uso da linguagem em interação social foram desenvolvidos principalmente por sociólogos, mas logo despertaram a atenção de estudiosos da linguagem. Em contraposição aos estudos de Chomsky, que estavam em voga na época, mas não contemplavam dados do desempenho de falantes, os trabalhos dos analistas propuseram a descrição da fala-em-interação. Entendiam que a conversa cotidiana era organizada e passível de análise e descrição (GARCEZ, 2008, p. 19).

A ACE, no entanto, não teve (ou tem) interesse no estudo da linguagem em si, mas na fala-em-interação de modo geral - embora considere que a organização da conversa tem sim um caráter primordial, servindo como base para estudos das outras formas (GARCEZ, 2008, p. 25).

A ACE ainda se preocupa "em chegar a uma descrição da ação social humana pela observação de dados de ocorrência natural dessa ação mediante o uso da linguagem" (GARCEZ, 2008, p. 22). Por essa razão, a descrição da ação social é calcada na observação, no registro e na transcrição de dados empíricos da fala-em-interação situada no tempo e no espaço, de ocorrência natural.

6 Pesquisa empírica dos métodos que os indivíduos utilizam para dar sentido e ao mesmo tempo realizar ações de todos os dias. 
Ligada à observação de dados está a valorização da perspectiva êmica, que "privilegia o ponto de vista da comunidade sob estudo e assim tenta descrever como os membros da comunidade atribuem sentido a um certo ato" (DURANTI, 1997, p. 172). Por isso, a ACE tem interesse em examinar "o que os participantes parecem registrar enquanto agem", "o que demonstram um para o outro" e "como fazem isso" (GARCEZ, 2008, p. 22), já que para ela, "a ação humana é necessariamente coconstruída e intersubjetiva por natureza" (2008, p. 25).

Nesse sentido, "para produzir uma elocução a cada dado momento, o participante da fala-em-interação precisa fazê-lo de tal modo que revele seu entendimento do que foi dito e do que feito anteriormente, e assim de novo a cada turno" (GARCEZ, 2008, p. 24):

\section{Quadro 1}

$1^{\mathrm{a}}$ posição A: elocução/ação individual proposta por A.

$2^{\mathrm{a}}$ posição B: elocução/ação individual proposta por B que revela entendimento da elocução e da ação individual de A em primeira posição.

$3^{\text {a }}$ posição A: elocução/ação individual proposta por $\mathrm{A}$ que revela $\mathrm{o}$ entendimento da elocução e da ação individual de B em segunda posição, e aceita o entendimento por parte de B do que A disse/fez em primeira posição.

Isso nos remete à noção de sequencialidade. Para a $\mathrm{ACE}$, a sequencialidade é considerada um constituinte central da ação social:

A noção de sequência refere-se ao fato de que as ações constituídas pelo uso da linguagem em interação social são organizadas em 'sequências' de elocuções produzidas por diferentes participantes. Cada participante, ao produzir sua elocução, não o faz de forma desordenada, mas sempre leva em consideração o que o outro disse previamente. (LODER; SALIMEN; MÜLLER, 2008, p. 40)

De acordo com Loder e colaboradores (2008, p. 41), há dois elementos principais decorrentes dessa noção de sequência: (1) as elocuções são produzidas de forma sucessiva e (2) a alternância dos participantes em tomar a palavra (p. 41).

Sacks aponta para o fato de que dada elocução constrange a posterior. Algumas delas, inclusive, se organizando sequencialmente em pares (SACKS, 2003, p. 4), os chamados pares adjacentes. Como exemplos mais comuns de 
pares adjacentes, podemos citar: pergunta-resposta, saudação-saudação, despedida-despedida, cumprimento-agradecimento, convite-aceitação ou recusa, pedido-concordância ou recusa, pedido de desculpas-perdão, entre outros. $\mathrm{Na}$ verdade, existe um ordenamento na realização das elocuções, ou seja, a saudação, por exemplo, cria a expectativa de outra saudação em resposta, pois "dada uma primeira parte, apenas algumas segundas partes são admissíveis e são produzidas" (SACKS, 2003, p. 521).

Essa relação entre um item a outro foi denominado por Schegloff (2003, p. 108) como relevância condicional: "dado o primeiro (par), o segundo é esperado; em ocorrendo, pode ser visto como um segundo item em relação ao primeiro; em não ocorrendo, pode ser visto oficialmente ausente". A ausência oficial do segundo item também leva os participantes a uma orientação específica a fim de atender a relevância condicional, podendo essas orientações ser observadas sob o formato de repetições, explicações, justificativas, entre outros.

Para Duranti, "por meio da análise de sequências como pares adjacentes, pode-se notar como a fala estabelece enquadres que evocam, sugerem, e até mesmo impõe certas expectativas aos participantes" sentido, "um par adjacente fornece um enquadre para a interpretação"8. (1997, p. 254).

O que nos leva a concluir que a intersubjetividade possui um papel central nesse processo, já que "as ações cotidianas se realizam em conjunto, sequencialmente, à medida que os participantes da ação convergem para um entendimento comum à ação proposta, refletida e aceita" (SCHEGLOFF apud GARCEZ, 2008, p. 31). Sendo assim:

\begin{abstract}
A intersubjetividade não seria, então, meramente a convergência entre múltiplos intérpretes de mundo (entendidos em termos de substância ou de procedimento), mas a convergência potencial entre os "realizadores" de uma ação ou parcela de conduta e seus recipientes, como coprodutores de um incremento de realidade interacional e social.
\end{abstract}

7 "By looking at sequences like adjacency pairs we can see how talk stablishes frames which evoke, suggest, and even impose certain expectations on participants" (DURANTI, 1997, p. 259)

8 "an adjacency pair provides a frame for interpretation" (DURANTI, 1997, p. 254) 
Tomando como exemplo a sala de aula, podemos observar que a intersubjetividade refere-se não apenas ao entendimento ou interpretação do aluno quanto ao que está sendo ministrado pelo professor, mas também no andamento da aula em si, já que ele também realiza a ação, sendo um de seus coprodutores.

Um dos elementos decorrentes da noção de sequência é organização de tomada de turno, que ocorre com a alternância dos participantes em tomar a palavra, ou seja, "fala um de cada vez".

Em seu artigo publicado em 1974, Sacks, Schegloff e Jefferson identificaram ainda algumas regras para a troca de turno. Em uma dada fala-eminteração, o falante corrente tendo terminado se turno pode: (a) identificar ou selecionar outro falante, que deverá para tomar o turno; (b) não selecionar outro falante e qualquer um poderá tomar o turno, se autosselecionar; (c) se ninguém se autosselecionar, continuar falando.

Embora o modelo estabelecido por Sacks e colaboradores sirva como orientação para análise da organização de turnos, Garcez adverte que a alocação de turnos de fala entre os participantes de uma dada interação é localmente produzida e sensível ao contexto (2008, p. 20). Por isso, a importância de se observar a fala-em-interação situada no tempo e no espaço, de ocorrência natural para a ACE.

Cabe ainda destacar que as interações entre dois ou mais falantes podem se apresentar de forma simétrica (em que os interlocutores têm igual participação durante a interação) ou assimétrica (um interlocutor detêm o uso da palavra e de sua distribuição), como, por exemplo, na sala de aula convencional, em entrevistas, em preleções e em consultas $(\mathrm{KOCH}, 2010$, p. 80).

A análise da organização do turno de fala (quem tem a vez de falar, quando fala, quem regula, ou seja, quem inicia o turno) bem como a estrutura organizacional da interação (como o turno é iniciado, como se desenvolve, como é finalizado) podem trazer grandes contribuições para estudos da fala-em-interação em contextos profissionais específicos, como veremos nesta pesquisa.

Outro aspecto relevante a ser observado é que os participantes de uma dada interação falam de um ou mais assuntos, que podem ser delimitáveis, constituindo o que se chama de tópico. Segundo Koch (2010, p. 81), "na linguagem comum, tópico é, portanto, aquilo sobre o que se fala". Durante a interação, vários assuntos são discutidos e, normalmente, não se passa de um 
assunto ao outro aleatoriamente, pois uma conversa não se trata de um enfileiramento de sucessivos turnos (MARCUSCHI, 2007, 75). Pelo contrário, "na conversação ${ }^{9}$, a perspectiva do desenvolvimento é múltipla; cada turno pode colocar uma reorientação, mudança ou quebra do ponto de vista em curso" (MARCUSCHI, 2007, p. 75). De acordo com Marcuschi:

Uma conversação fluente é aquela em que a passagem de um tópico a outro se dá com naturalidade, mas é muito comum que a passagem de um tópico a outra seja marcada. Os marcadores de introdução de tópico não funcionam apenas para indicar que se está passando para algo novo, mas que esta passagem tem alguma razão de ser e deve ser notada (caso contrário, pode surgir a pergunta: 'por que isso agora?'). (2007, p.77)

Outra distinção importante que deve ser observada na interação que é a diferença entre falar topicamente e falar sobre o tópico. Segundo Coulthard (COULTHARD apud MARCUSCHI, 1997, p. 80), "é possível que vários falantes sucessivos falem topicamente sem se aterem ao mesmo tópico, ou seja, preservase a coerência embora mude o tópico". Por exemplo, um grupo de amigos falando sobre seus destinos turísticos preferidos: cada qual pode descrever um lugar sem se deterem em único específico, ainda que eles não estejam falando sobre o mesmo tópico (Recife, Bahia, etc.), a conversa não perde a coerência, pois eles falam topicamente.

\section{- A sequência IRA (Iniciação-Resposta-Avaliação)}

Se tomarmos a sala de aula convencional como referência, podemos observar que a organização nesse contexto institucional, recorrentemente, se estabelece por meio de sequências previsíveis (2006, p. 68). Essas sequências foram descritas por Sinclair e Coulthard (1975) e outros da seguinte forma:

- Professor: Iniciação

- Aluno: Resposta

- Professor Avaliação

9 Apesar de utilizar o termo "conversação", entendemos que o mesmo é empregado com o mesmo sentido de "conversa" neste contexto específico. 
Segundo Garcez, é "a observação dessa sequência em andamento que nos traria o reconhecimento de que se trata de fala-em-interação de sala de aula convencional" (2006, p. 68).

Ao analisarmos essa sequência, podemos ainda concluir que a mesma traz em si uma premissa. O primeiro turno, chamado de Iniciação, frequentemente se estabelece por uma pergunta cuja resposta já é conhecida (GARCEZ, 2006, p.68).

As perguntas utilizadas nesse contexto institucional específico são sempre consideradas "perguntas-teste", "perguntas para demonstração", ou seja, "perguntas de informação conhecida". Inclusive, segundo Garcez: "o termo que nomeia o turno de fala na primeira posição da sequência - Iniciação - só faz sentido se levarmos em conta seu objeto, aquilo que se concretiza no turno de terceira posição, ou seja, na fala subsequente do 'iniciador': a Avaliação”. Sendo assim, a sequência definidora de sala de aula convencional é uma sequência avaliativa (2006, p. 69).

Se, por acaso, o aluno não "erra" a resposta de acordo com a avaliação do professor, ele é imediatamente corrigido por este último. Nesse caso, a correção contribui para ratificar o status do professor como detentor do conhecimento e para reforçar a hierarquia em sala (GARCEZ, 2006, p. 69).

Além disso, vale destacar que, raramente, pode ser observado engajamento no segundo turno do aluno para a construção de conhecimento, já que o objetivo é conseguir a aprovação do professor, configurando-se quase um jogo em que o que importa é acertar a resposta, ou quase "ler a mente" do professor (GARCEZ, 2006 ,

p. 69).

A partir desse exame, pode-se concluir que tal sequência é propícia para um ambiente onde se dá a reprodução de conhecimento, pois já não importa a construção conjunta, o que vale é aceitar o que já é trazido como verdade (p. 69).

Neste capítulo, fornecemos uma visão geral sobre as bases teóricas utilizadas para esta pesquisa. No próximo, apresentamos os procedimentos metodológicos adotados. 


\section{Metodologia da Pesquisa}

Este capítulo apresenta a metodologia do presente estudo, o contexto investigado, os procedimentos de geração e análise de dados. O capítulo se subdivide em quatro partes. Na primeira, retomamos os objetivos e as questões da pesquisa. $\mathrm{Na}$ segunda, traçamos uma descrição da pesquisa, apontando a metodologia adotada. Logo a seguir, descrevemos o contexto. Por fim, na quarta parte, apresentamos os procedimentos de geração e de análise de dados.

\section{1}

\section{Objetivo da pesquisa}

Conforme apresentado no capítulo 2, os avanços das TICs e a ampliação das políticas públicas, visando ao aumento do acesso à educação proporcionaram o salto da EAD no país.

No estágio atual, segundo Pierre Lévy, vemos que a ampla utilização de uma gama de novas tecnologias na educação traz, em seu bojo, mudanças na nossa relação com o saber (2008, p.157). De acordo com ele:

\footnotetext{
A EAD explora certa técnicas de ensino a distância, incluindo as hipermídias, as redes de comunicação interativas e todas as tecnologias intelectuais da cibercultura. Mas o essencial se encontra em um novo estilo de pedagogia, que favorece ao mesmo tempo as aprendizagens personalizadas e a aprendizagem coletiva em rede. Nesse contexto, o professor é incentivado a tornar-se um animador da inteligência coletiva de seus grupos de alunos em vez de um fornecedor direto de conhecimentos. (LÉVY, 2008, p. 158)
}

No entanto, apesar do acesso a tantos recursos, questiona-se até que ponto esse professor do ambiente virtual atua mesmo como um facilitador do conhecimento do grupo e os alunos como agentes da construção de saberes coletivos.

Dessa forma, o principal objetivo deste trabalho é investigar como tutor e aluno de curso a distância gerenciam as possibilidades da tecnologia para 
construção de um novo ambiente de aprendizagem. Para tal, foram formulados os seguintes objetivos intermediários:

i) identificar os papéis de atividade e os papéis discursivos que emergem no modo como o tutor interage na sala de aula virtual;

ii) identificar que modelo pedagógico subjaz à organização das trocas interacionais no cenário virtual.

\section{2}

\section{Caracterização da pesquisa}

O presente estudo insere-se em uma pesquisa de natureza qualitativa e interpretativa. De acordo com Denzin e Lincoln, os pesquisadores qualitativos "buscam soluções para as questões que realçam o modo como a experiência social é criada e como adquire significado" (2006, p. 23), o que corrobora para o objetivo central deste estudo (investigar como tutor e aluno de curso a distância gerenciam as possibilidades da tecnologia para construção de um novo ambiente de aprendizagem).

Além disso, a opção do estudo de caso como método também coaduna com essa premissa, pois o mesmo atende a estudos cujas questões da pesquisa "procuram explicar alguma circunstância presente (por exemplo, "como" ou "por que" algum fenômeno social funciona)" (YIN, 2010, p. 24).

Optamos ainda por um estudo de caso único por a sala de aula em questão se caracterizar como uma sala de aula típica ou representativa, existindo um modelo de tutoria que é replicado em todas as disciplinas do programa a distância, não havendo distinção entre as várias disciplinas oferecidas e não importando a área do conhecimento. O objetivo então é captar as circunstâncias de uma situação diária ou lugar-comum (YIN, 2010, p. 72).

Essa pesquisa se insere ainda na área da Linguística Aplicada das Profissões (LAP). A LAP elege um contexto amplo de profissões como temática de trabalho. Segundo Sarangi, a LAP leva em consideração: 
(...) especificamente a prática do conhecimento produzido em domínios profissionais, tais como a lei, a saúde, a mídia, a organização, a interpretação, a tradução etc., enfim, em campos profissionais em que a atividade é focada na linguagem. Há um compromisso dos pesquisadores em construir conhecimento novo sobre uma prática profissional com base num ferramental teórico próprio dos estudos da linguagem. (GARCEZ; FRANK; KANITZ, 2012, p. 168)

Nesse caso, o referencial teórico se apoia: (i) na visão de Hutchby (2001) quanto às possibilidades e restrições da utilização de artefatos tecnológicos; (ii) nos estudos de papéis sociais e papéis de atividade dos trabalhos de Merton (1968), Goffman (Levinson, 1979) e Sarangi (2010, 2011); (iii) nas contribuições de Harvey Sacks, Emanuel A. Schegloff e Gail Jefferson (2003[1974]) e Garcez $(2006,2008)$ quanto às trocas interacionais.

\section{3}

\section{Contexto da pesquisa}

Esta pesquisa foi realizada a partir da análise das mensagens trocadas entre a tutora e alunos em sala de aula (um fórum de discussão) de uma disciplina do curso de MBA em Gestão Pública de uma universidade carioca.

A instituição oferece cursos de graduação e pós-graduação, principalmente na área de Humanidades. O curso de MBA, por sua vez, tem 410 horas, sendo 360 presenciais e 50 a distância. A disciplina que serviu como base para este estudo é a quarta em andamento do curso, Gestão de Marketing.

A universidade utiliza o Moodle como plataforma de aprendizagem. O Moodle trata-se de um "Course Management System (CMS), também conhecido como Learning Management System (LMS) ou Ambiente Virtual de Aprendizagem (AVA), que é um aplicativo web gratuito que os educadores podem utilizam na criação de sites de aprendizado" (MOODLE.ORG.BR, 2013).

O ambiente virtual do curso é dividido nas seguintes seções:

$\checkmark$ área de estudos: área com conteúdo teórico e atividades da disciplina;

$\checkmark$ biblioteca: área com recursos multimídia, conteúdo complementar;

$\checkmark$ sala de aula: fórum de discussão onde os alunos podem interagir com uns com os outros e com o tutor da disciplina. 
Neste trabalho, foi dado enfoque apenas a sala de aula (fórum de discussão), ou seja, foram analisadas as mensagens trocadas pelo tutor e pelos alunos (552 mensagens, sendo 180 publicadas pelo tutor; e 372, publicadas pelos alunos).

\section{- Participantes}

A turma era composta em sua maioria por funcionários públicos de diversas localidades do país. Com fins de preservar a identidade tanto do tutor quanto a dos alunos, utilizamos numerações para representá-los e trocamos os nomes por outros em alguns trechos dos dados.

\section{- O modelo de tutoria}

O tipo de tutoria adotado no programa é proativo. Nesse caso, o tutor não tem apenas a responsabilidade de responder às dúvidas dos alunos, mas trazer questões para o debate. $\mathrm{Na}$ instituição estudada, o tutor passa por um treinamento interno antes de assumir uma disciplina. Ao participar desse treinamento, esse profissional recebe um manual que deve guiar as ações dele em sala de aula. Esse documento traz uma série de informações sobre o modelo pedagógico adotado, uma relação com as diversas atribuições e atividades que ficarão sob responsabilidade do tutor, além de método de avaliação dos alunos e do próprio profissional.

Importa-nos aqui esclarecer que esse manual constitui uma espécie de tutorial que orienta as ações do tutor em sala de aula, sendo o mesmo avaliado por realizar (ou não) algumas atividades. Essa avaliação não tem caráter qualitativo, pois prevê apenas se houve ou não o cumprimento das atividades.

\section{4}

\section{Geração e análise de dados}


Visando a geração de dados para esta pesquisa, foi solicitada à instituição a permissão para se observar algumas turmas dos tutores mais bem avaliados pelo programa. Em resposta, recebemos acesso para acompanhar como se deu o andamento de 23 disciplinas que já haviam sido encerradas.

A análise de dados se deu em três momentos. Primeiramente, fizemos a leitura do manual de procedimentos e, logo a seguir de, pelo menos, três tópicos de cada sala de aula de quatro das disciplinas que obtemos acesso (Boas-Vindas, Módulo 1, Módulo 3).

\section{- Análise dos papéis da atividade: origem dos termos}

Por entendermos que o papel do tutor está ligado à atividade em questão (SARANGI, 2010, p. 39), classificarmos seu papel com os seguintes termos:

$\checkmark$ orquestrador: responsável por conduzir todas as ações. Esse papel de atividade compreende subpapéis, como o de condutor, expositor, incitador do debate, avaliador e editor.

$\checkmark$ mediador: responsável por mediar as relações entre alunos e o suporte técnico, o conteudista e a própria instituição.

$\checkmark$ animador/motivador: responsável por incentivar à participação dos alunos.

\section{- Análise da troca interacional}

Como o modelo pedagógico prevê uma espécie de calendário em que o tutor deve realizar determinadas atividades como, por exemplo, postar mensagem de boas-vindas à turma (até dois dias antes da data de início), abrir uma discussão para cada módulo, discutindo e criando propostas para debate (diariamente), atualizar boletim (sábados, domingo ou às segundas), etc., entendemos que essas tarefas se repetem ao longo do andamento de todas as disciplinas; por isso, escolhemos analisar as mensagens de apenas uma das disciplinas observadas (no caso, Gestão de Marketing na Administração Pública) e utilizá-las como exemplos na Análise de Dados.

Compreendemos ainda que as participações nos tópicos de discussão em sala também seguem um padrão: 
Tópico Boas-Vindas: o tutor publica uma mensagem se apresentando e incentivando os alunos a se apresentarem também.

Tópico Módulo X: o tutor publica uma mensagem lançando uma questão para o debate ou solicitando que os alunos comentem textos complementares. Os alunos respondem à solicitação, e o tutor fornece um feedback.

Tópico de Orientação da Atividade: o tutor publica uma mensagem com orientações sobre a atividade proposta para a disciplina.

Nesse último caso, observamos que as respostas dos alunos seguem o seguinte padrão:

$\checkmark$ a fala social: mensagens contendo incentivos à participações ou emoticons;

$\checkmark$ a dúvida técnica: mensagens com dúvidas sobre o ambiente, acesso a links, etc.

$\checkmark$ o resumo: mensagens com resumos da leitura dos textos complementares

$\checkmark$ pedido de esclarecimento: mensagens com dúvidas relacionadas ao conteúdo;

$\checkmark$ a iniciação para o debate (potencial de ser resposta e iniciação para outros): mensagens com dúvidas dos alunos que são respondidas por outras, gerando um debate.

Abaixo, segue um resumo com o número de publicações em sala de aula como forma de apresentar um panorama da participação da turma em cada semana (S0, S1, S2 ...). Vale esclarecer que o número entre parênteses são as participações consideradas como qualitativas (que não sejam apenas emoticons, frases soltas, etc.)

\begin{tabular}{|l|c|c|c|c|c|c|c|c|c|c|}
\hline Autor & S0 & S 1 & S 2 & S 3 & S 4 & S5 & S6 & S7 & Total & Total \\
\hline Aluno 1 & & & & & & & & & & \\
\hline Aluno 2 & $4(1)$ & $2(2)$ & $2(2)$ & $2(2)$ & $2(2)$ & $5(4)$ & & & $17(13)$ & 13 \\
\hline Aluno 3 & $1(1)$ & $5(3)$ & & $4(2)$ & & & & & $10(6)$ & 6 \\
\hline Aluno 4 & & $3(0)$ & $2(2)$ & $1(1)$ & $2(2)$ & $2(2)$ & & $1(0)$ & $11(7)$ & 7 \\
\hline
\end{tabular}




\begin{tabular}{|l|c|c|c|c|c|c|c|c|c|c|}
\hline Aluno 5 & $2(1)$ & $1(0)$ & & & & & $1(0)$ & & $4(1)$ & 1 \\
\hline Aluno 6 & $1(0)$ & $1(1)$ & $3(3)$ & $11(8)$ & $3(3)$ & $4(4)$ & & & $23(19)$ & 19 \\
\hline Aluno 7 & & $5(1)$ & & & $3(3)$ & $2(2)$ & & & $10(6)$ & 6 \\
\hline Aluno 8 & & $2(0)$ & $7(5)$ & $8(5)$ & $2(2)$ & $4(3)$ & $1(0)$ & & $24(15)$ & 15 \\
\hline Aluno 9 & $1(1)$ & $3(1)$ & $3(2)$ & $2(2)$ & $3(3)$ & $2(1)$ & $2(1)$ & $1(0)$ & $17(11)$ & 11 \\
\hline Aluno 10 & $5(0)$ & $6(2)$ & $8(3)$ & $8(5)$ & $7(3)$ & $6(2)$ & & $1(0)$ & $41(15)$ & 15 \\
\hline Aluno 11 & $4(1)$ & & & $6(6)$ & $9(9)$ & $1(1)$ & & & $20(17)$ & 17 \\
\hline Aluno 12 & & $2(1)$ & $1(1)$ & & $2(2)$ & $1(0)$ & & & $6(4)$ & 4 \\
\hline Aluno 13 & $3(0)$ & $8(1)$ & $6(0)$ & $8(6)$ & $1(0)$ & & $2(0)$ & & $28(7)$ & 7 \\
\hline Aluno 14 & $4(1)$ & $4(4)$ & $7(6)$ & $5(2)$ & $5(5)$ & $7(7)$ & & & $32(25)$ & 25 \\
\hline Aluno 15 & $3(0)$ & $2(1)$ & $8(4)$ & $8(8)$ & $2(2)$ & $12(7)$ & & & $35(22)$ & 22 \\
\hline Aluno 16 & & & & $11(9)$ & $1(1)$ & & & & $12(10)$ & 10 \\
\hline Aluno 17 & $4(2)$ & & $3(3)$ & $1(1)$ & $1(1)$ & $4(4)$ & $2(1)$ & & $15(12)$ & 12 \\
\hline Aluno 18 & $1(1)$ & $1(1)$ & $6(4)$ & $4(4)$ & $3(2)$ & $2(1)$ & & & $17(13)$ & 13 \\
\hline Aluno 19 & & $1(0)$ & & & $5(5)$ & $2(1)$ & $2(2)$ & & $10(8)$ & 8 \\
\hline Tutora & $\mathbf{1 5}(0)$ & $\mathbf{3 0}(0)$ & $\mathbf{1 8 ( 0 )}$ & $\mathbf{5 4}(\mathbf{0})$ & $\mathbf{3 7}(0)$ & $\mathbf{2 1 ( 0 )}$ & $\mathbf{5 ( 0 )}$ & & $\mathbf{1 8 0}(\mathbf{0})$ & $\mathbf{1 8 0}$ \\
\hline Aluno 20 & & $1(1)$ & & $2(0)$ & & $2(2)$ & $1(1)$ & & $6(4)$ & 4 \\
\hline Aluno 21 & $2(0)$ & $6(2)$ & $1(1)$ & & $7(4)$ & $6(6)$ & & & $22(13)$ & 13 \\
\hline Aluno 22 & $1(0)$ & & & & $3(3)$ & & & & $4(3)$ & 3 \\
\hline Aluno 23 & $4(1)$ & & & & & $1(1)$ & & & $5(2)$ & 2 \\
\hline Aluno 24 & $1(0)$ & $3(0)$ & $4(3)$ & & $9(3)$ & $4(3)$ & $1(0)$ & & $22(9)$ & 9 \\
\hline Aluno 25 & $5(0)$ & & $2(2)$ & $11(8)$ & $3(3)$ & $3(3)$ & & & $24(16)$ & 16 \\
\hline Aluno 26 & & $15(4)$ & $4(4)$ & $5(4)$ & $7(7)$ & $1(1)$ & & & $32(20)$ & 20 \\
\hline Aluno 27 & $2(0)$ & $7(4)$ & $2(1)$ & $6(4)$ & $5(5)$ & $8(8)$ & & & $30(22)$ & 22 \\
\hline Aluno 28 & $3(1)$ & $3(2)$ & & $4(3)$ & $4(4)$ & $7(6)$ & $1(1)$ & & $22(17)$ & 17 \\
\hline Aluno 29 & $6(1)$ & $7(4)$ & $2(2)$ & $4(1)$ & $5(5)$ & $3(2)$ & $1(0)$ & & $28(15)$ & 15 \\
\hline Aluno 30 & $2(0)$ & $4(4)$ & $3(3)$ & $6(4)$ & $3(3)$ & $9(8)$ & $1(0)$ & & $28(22)$ & 22 \\
\hline Aluno 31 & & & & & & & & & $0(0)$ & 0 \\
\hline Aluno 32 & $2(0)$ & $1(0)$ & $1(1)$ & $2(2)$ & $5(5)$ & $2(1)$ & & & $13(9)$ & 9 \\
\hline Aluno 33 & $3(1)$ & & & $1(1)$ & $4(4)$ & $4(3)$ & & & $12(9)$ & 9 \\
\hline
\end{tabular}

Tabela 2 (número de participações em sala de aula)

Neste capítulo, caracterizamos a metodologia de pesquisa deste estudo, descrevendo o contexto investigado, os procedimentos de geração e de análise de dados. No próximo capítulo, passaremos a análise dos dados propriamente dita. 


\section{Os papéis da atividade do tutor na sala de aula virtual}

Há uma vasta literatura sobre o papel do tutor on-line, que, geralmente, está atrelado a várias competências a serem exercidas por esse profissional. No entanto, entendemos que uma análise dos papéis da atividade pode nos levar a uma melhor compreensão sobre os papéis desempenhados pelo tutor. Conforme já apresentado, o papel da atividade é dependente do tipo de atividade em que o indivíduo está participando e, usualmente, é definido em relação a outros participantes (SARANGI, 2010, p. 39). Neste capítulo, nosso foco são os papéis do tutor, no ambiente virtual, com relação aos alunos. Na seção 5.1, examinamos os papéis do tutor na área pedagógica, técnica e social (TELES et al, 2000). Na seção 5.2, identificamos três grandes papéis de atividade: o de orquestrador (5.2.1), o de mediador (5.2.2) e o de motivador/animador (5.2.3).

\section{1}

\section{Os papéis do tutor na área pedagógica, técnica e social}

Como aponta a literatura, podemos identificar três grandes áreas de atuação do tutor. Para ilustrar os papéis do tutor nas áreas pedagógica, técnica e social, analisamos a primeira aula do curso em estudo. Para melhor acompanhar a descrição desses papéis, recortaremos a mensagem de abertura do curso, publicada no fórum de Boas-Vindas, considerando os tópicos e as ações realizadas pelo tutor.

\section{- A autoapresentação}

No excerto seguinte, focalizamos a abertura da mensagem, que mostra o modo como o tutor procura criar uma identidade (como será também pedido aos alunos). Numa primeira aula presencial, nem sempre os alunos se apresentam, e os professores se limitam a dizer seu nome. O reconhecimento de quem é o professor ou cada aluno é construído a partir de inferências sobre o comportamento verbal e não verbal do outro. No ambiente virtual, a falta de 
visibilidade é compensada por ações que promovam o reconhecimento das diferentes identidades dos participantes.

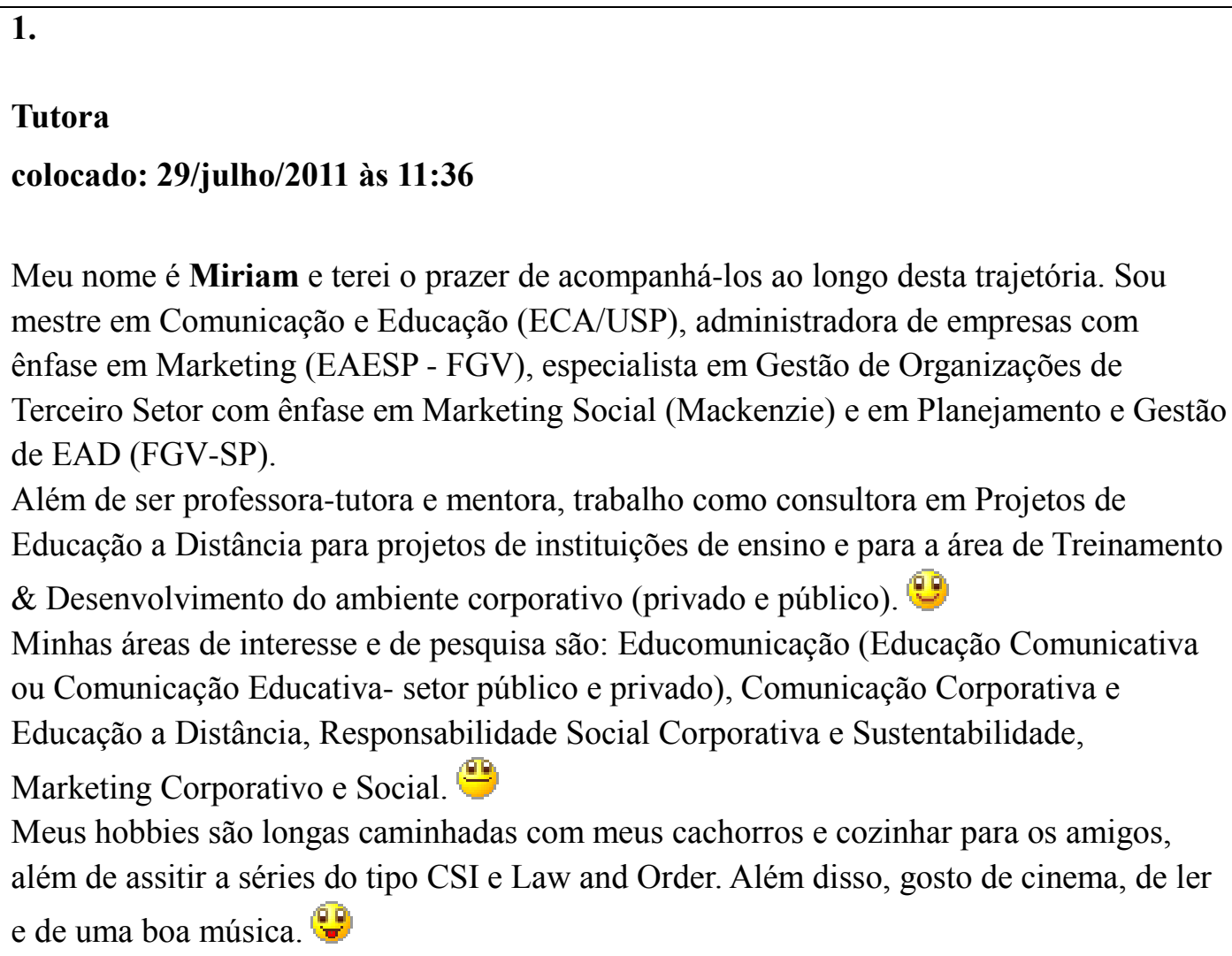

Meu nome é Miriam e terei o prazer de acompanhá-los ao longo desta trajetória. Sou mestre em Comunicação e Educação (ECA/USP), administradora de empresas com ênfase em Marketing (EAESP - FGV), especialista em Gestão de Organizações de Terceiro Setor com ênfase em Marketing Social (Mackenzie) e em Planejamento e Gestão de EAD (FGV-SP).

Além de ser professora-tutora e mentora, trabalho como consultora em Projetos de Educação a Distância para projetos de instituições de ensino e para a área de Treinamento \& Desenvolvimento do ambiente corporativo (privado e público).

Minhas áreas de interesse e de pesquisa são: Educomunicação (Educação Comunicativa ou Comunicação Educativa- setor público e privado), Comunicação Corporativa e Educação a Distância, Responsabilidade Social Corporativa e Sustentabilidade, Marketing Corporativo e Social.

Meus hobbies são longas caminhadas com meus cachorros e cozinhar para os amigos, além de assitir a séries do tipo CSI e Law and Order. Além disso, gosto de cinema, de ler e de uma boa música.

A tutora inicia seu turno dando as boas-vindas ("terei o prazer de acompanhá-los") e se apresentando não apenas pelo nome. Ela faz uma autoapresentação muito semelhante à de um currículo. Inicia pela sua formação ("mestre em Comunicação"), sua experiência profissional, destacando diferentes papéis sociais (professora, tutora, mentora, consultora). Além disso, ela busca se apresentar também como indivíduo, falando de seus hobbies (último parágrafo).

\section{- A apresentação do ambiente virtual}

A tecnologia possibilita uma educação em tempo e espaço diferenciado e com uma desejável participação maior da turma. No entanto, ela também exige algum trabalho para dominar o sistema. Em função disso, o tutor inclui, na Primeira Aula, informações sobre a EAD. 
2.

Tanto para quem já atendeu a algum curso neste modelo, como para os iniciantes, relembro que a educação a distância tem algumas peculiaridades. Apesar das dificuldades que alguns de vocês encontram em transitar no ambiente virtual no início, essas se dissolvem rapidamente. E vocês descobrem o quão interessante e consistente é a construção conjunta do conhecimento no meio virtual.

Contudo, caso persistam dúvidas referentes à área técnica, sobre como navegar o LearningSpace e onde encontrar o material e outros do gênero, existe a equipe do Suporte, para ajudá-los no que for preciso.

No primeiro parágrafo, vemos que a tutora assume implicitamente o medo dos alunos com relação à mediação tecnológica, mas enfatiza o benefício que essa tecnologia pode trazer para o processo de aprendizagem. Logo em seguida, ela se destitui do papel de mediadora para os casos de problemas técnicos, apresentando a equipe de Suporte como o interlocutor apropriado para os problemas nessa área.

\section{- Apresentação do programa}

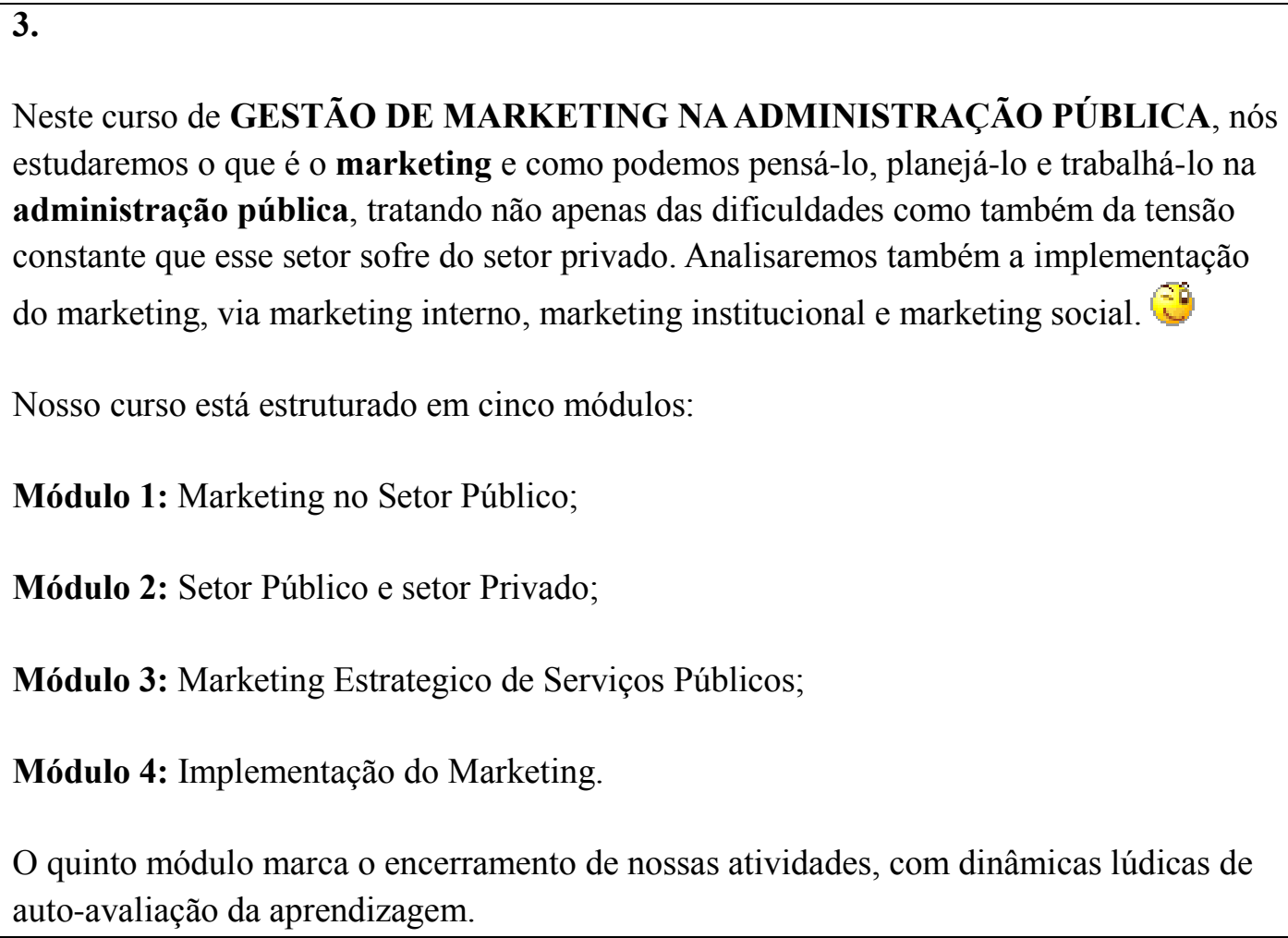
estudaremos o que é o marketing e como podemos pensá-lo, planejá-lo e trabalhá-lo na administração pública, tratando não apenas das dificuldades como também da tensão constante que esse setor sofre do setor privado. Analisaremos também a implementação do marketing, via marketing interno, marketing institucional e marketing social.

Nosso curso está estruturado em cinco módulos:

Módulo 1: Marketing no Setor Público;

Módulo 2: Setor Público e setor Privado;

Módulo 3: Marketing Estrategico de Serviços Públicos;

Módulo 4: Implementação do Marketing.

O quinto módulo marca o encerramento de nossas atividades, com dinâmicas lúdicas de auto-avaliação da aprendizagem.

Depois de falar sobre o meio, o tutor apresenta o conteúdo programático, o 
objeto de estudo, a estrutura do curso num modelo muito semelhante ao de uma primeira aula do ensino presencial.

\section{- O pré-fecho}

4.

Tenho que admitir que estou ansiosa para explorar cada um desses conteúdos com vocês, discutindo e trazendo nossas contribuições, dúvidas e dilemas para a nossa sala de aula interativa!

Em breve, iniciarei as discussões conceituais do Módulo 1 em sala de aula, iniciando uma temporada de aprendizagem mútua, atrelada a um clima de cooperação, cumplicidade e proximidade.

Aproveitem estes primeiros dias para explorar e/ou relembrar como se navega pelo nosso ambiente on-line de aprendizagem. 98

Participar é fundamental!

No pré-fecho, a tutora retoma seus papéis na área pedagógica, social e técnica. Inicia, reiterando sua atitude de entusiasmo com a riqueza da troca e com um modelo de aprendizagem interativo, evocando expectativas de grande participação: aluno-tutor e aluno-aluno. Em seguida, reassume o seu papel na área pedagógica, indicando as primeiras tarefas e reforçando as condições para o sucesso do trabalho. Logo depois, atua como orientadora na área técnica, ao reapresentar a EAD pelo seu diferencial: aprendizagem mútua, clima de cooperação, cumplicidade e proximidade. E finaliza, voltando ao seu papel pedagógico, ao chamar a atenção para a participação como condição de aprendizagem.

\section{- O fechamento}

No fechamento, a tutora volta a desempenhar tarefas relacionadas à área social, incentivando os alunos a se apresentarem. 
5.

Uma sugestão inicial: que tal adicionar um comentário a esta mensagem em sala de aula, registrando suas expectativas em relação a esta disciplina e dando as boas-vindas aos colegas? Isso representa, ainda, ferramentas, não acham? Aproveitem para relatar também um pouco mais sobre as suas experiências pessoais e profissionais. Assim, poderemos nos conhecer melhor!

Sejam muito bem-vindos ao curso de Gestão de Marketing na Administração Pública! Abraços a todos e um excelente trabalho!

Como na abertura, vemos como a tutora torna relevante a necessidade de lidar com a restrição da tecnologia ao contato visual. Sob o enquadre de uma sugestão, ela orienta os alunos a se apresentarem, falarem de si e de suas expectativas. Vê-se que o apelo à participação é dominante no turno da tutora, e há um esforço para que as pessoas se conheçam, o que pode contribuir para a criação de um ambiente amigável, que promova um clima de cooperação entre os participantes, favorecendo a coesão do grupo.

Apesar de a análise evidenciar que os papéis do tutor estão relacionados a áreas específicas, defendemos aqui que a visão de que uma análise dos papéis da atividade pode nos levar a uma melhor compreensão sobre os papéis desempenhados pelo tutor num dado ambiente virtual de EAD.

\section{2}

\section{Os papéis da atividade}

Como descrito por Sarangi (2010, p. 39), o papel da atividade é dependente do tipo de atividade em que o indivíduo está participando. No caso em estudo, observamos que o tutor desempenha três papéis da atividade: o de orquestrador; o de mediador e o de animador/motivador.

\subsection{1}

\section{O papel de orquestrador}


Esse papel de atividade compreende subpapéis, como o de condutor, expositor, incitador do debate, avaliador e editor. $\mathrm{Na}$ sequência seguinte, identificamos por meio da análise dos papéis discursivos alguns desses subpapéis:

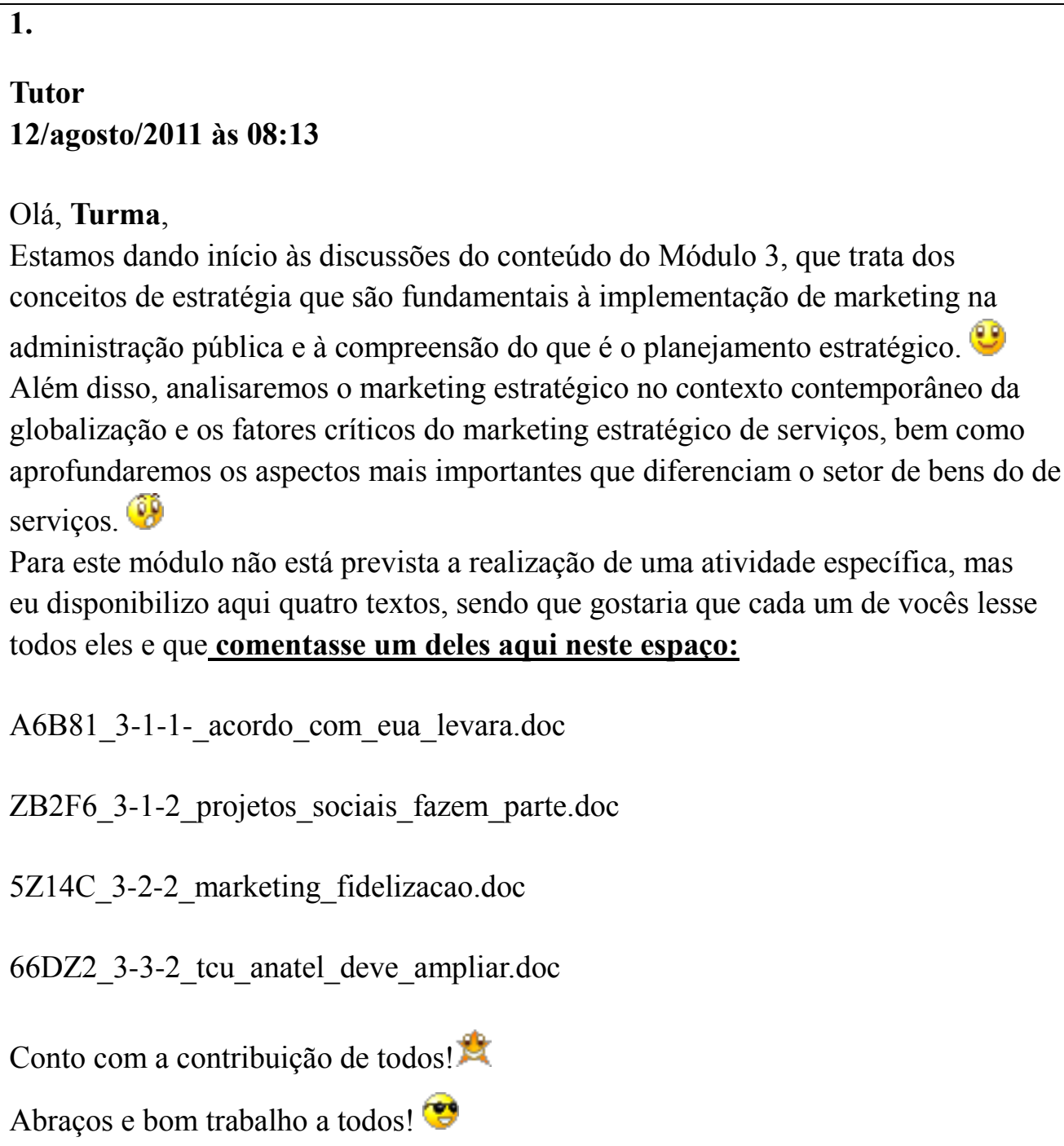

Em seu turno de abertura do módulo, o tutor se apresenta como orquestrador, nos papéis de condutor do módulo, da atividade e da troca conversacional. Como condutor do módulo e da atividade, ele apresenta o conteúdo, fornece o material e propõe uma atividade.

De um modo geral, os alunos não atendem ao convite do tutor, trazendo uma contribuição que favoreça um debate e estimule os colegas a participarem. 
Uma rara exceção é a que se segue, o que já é anunciado numa saudação que inclui tutor e colegas como destinatários:

\section{2.}

Aluno 3

colocado: 13/agosto/2011 às 11:53

Bom dia Prof. e colegas!

No texto "Projetos sociais já fazem parte do planejamento estratégico das empresas", o autor destaca o processo irreversível de conscientização das organizações sobre o que é e a importância da responsabilidade social.

Como não acredito muito em consciência pela consciência no mercado, ou seja, em uma tendência de que organizações competitivas se tornem "simplesmente boas", acabo sendo cético com declarações como a do presidente da Petrobrás, dizendo que não é um estratégia para fortalecer a imagem da instituição, mas para melhorar as condições de vida da sociedade. O mercado é feito de dura competição pela sobrevivência e crescimento.

Logo no final do texto meu ceticismo começa a se justificar com a citação de uma entrevista que aponta a responsabilidade social como fator que influencia a preferência de consumidores.

Logo adiante, lendo o texto "Sustentabilidade global e governança pública" e estudando os conceitos sobre qualidades de procura alta, experiência alta e crença alta "liguei os pontos" (gráfico muito interessante do item 3.2.1) e formei opinião.

$\mathrm{O}$ mecanismo que obriga as organizações a investir em práticas de responsabilidade social é a necessidade de construir uma imagem de confiança no longo prazo, com a prática de valores como honestidade, responsabilidade, consideração e transparência. Enfim, é a evolução da consciência da SOCIEDADE que obriga empresas a alterarem suas estratégias a fim de manterem-se competitivas.

Pergunto / Provoco: Isso é ou não uma evidência que o capitalismo evolui? Independente do mecanismo, forçada ou não, considero essa adaptação da estratégia das organizações algo a se comemorar.

Abraço a todos!

O aluno 3 traz uma contribuição qualitativa para a sala, relacionando a leitura dos textos sugeridos e levantando uma questão para toda a turma iniciadora de debate ("Pergunto/Provoco: Isso é ou não uma evidência que o capitalismo evolui?’).

A tutora, como mostra o exemplo a seguir, conduz também a troca conversacional: 


\begin{abstract}
3.
Tutora

colocado: 13/agosto/2011 às $21: 23$

Olá, Guilherme,

Achei muito interessantes suas reflexões quanto à questão da consciência.

Eu dou aula de sustentabilidade na pós graduação da ECA/USP, sendo que uma das coisas que costumo comentar é que sustentabilidade tem a ver principalmente com a cultura das pessoas. E como mudar cultura, principalmente de adultos, leva tempo e demanda reeducação constante, essa mudança está levando mais tempo do que deveria. Já que você lançou uma reflexão, gostaria de reforçá-la e complementá-la. Lembro que organizações são formadas por pessoas, pelas pessoas que a compõem. Então, será que são as organizações ou as pessoas que estão mais participativas, conscientes e lutando por um plante melhor?

Abraços e bom final de semana a todos!
\end{abstract}

Ao responder à provocação do aluno, a tutora desempenha vários subpapéis da atividade de orquestrador. Ele avalia a contribuição do aluno, ele faz uma exposição sobre o tópico, ampliando o escopo da questão levantada; ela abre, por meio de uma pergunta, um outro ponto para debate.

Apesar de seu esforço em tentar criar um ambiente propício à aprendizagem colaborativa, as mensagens subsequentes não consideram a pergunta colocada. Só o aluno que propôs a questão é que responde à questão levantada pela tutora:

4.

Aluno 3

colocado: 16/agosto/2011 às 09:04

Bom dia professora!

Concordo contigo que as organizações são as pessoas que as compõem, mas entendo que são muito mais do que a soma das individualidades dessas. Acredito que no âmbito interno, o institucional, as pessoas tendem a agir de acordo com a Teoria da ação coletiva e grupos de interesse (de quem é mesmo??), ou seja, agem pelo interesse do grupo em detrimento do interesse geral.

Também não saberia dizer se as pessoas, a sociedade em geral, está mais participativa ou se a percepção geral média foi mudando a ponto de relacionar a imagem de confiança a longo prazo com os valores implícitos em ações de responsabilidade social. Enfim, ao meu ver, entre os diversos grupos de interesse (organizações com fins lucrativos, imprensa, ativistas sociais e etc), acredito que a opinião pública média foi 
migrando naturalmente, quase que involuntariamente e seus valores foram em direção à valorização da responsabilidade social.

Abraço!

Do mesmo modo, ao comentar as contribuições dos alunos ao final de uma atividade, a tutora enfatiza apenas o seu papel de avaliador, não buscando no decorrer da conversa criar oportunidades para uma aprendizagem colaborativa. A tutora não corrige o rumo que toma a interlocução na sala, não interfere de forma a tornar aprendizagem mais dinâmica, assumindo um papel apenas de avaliador das respostas dos alunos.

Um exemplo é o caso em que a tutora pede uma atividade relacionada aos 4 Ps de marketing:

\section{5.}

Tutora

SUGESTÃO DE DEBATE: Peço que descrevam brevemente o serviço público que escolheram analisar, quais seriam as bases da definição do preço desse produto, qual a praça onde ele é oferecido, como se dá a promoção/comunicação do mesmo junto aos cidadãos, quais seriam as formações específicas das pessoas que o prestam, como seria o perfil físico da localidade onde são prestados e listem de 4-5 procedimentos básicos que compõem o processo dessa prestação de serviços.

Caso tenham alguma dúvida na montagem desse exemplo, não hesitem em me perguntar. O objetivo aqui é que passem a refletir sobre os P's de Marketing junto à gestão pública, para que comecem a entender melhor como se dá isso.

A participação de todos é importante, pois os vários exemplos diferenciados mostrarão a vocês como não existe receita pronta e como a estratégia de cada um dos $\mathrm{P}^{\prime}$ s está ligada às estratégias dos demais.

A proposta abre espaço para que os alunos ajustem os conhecimentos apresentados sobre os 4 Ps à sua realidade. No entanto, a proposta já inclui a conclusão a que se deve chegar: não existe receita pronta, e a estratégia de cada um dos Ps está ligada às estratégias dos demais. A tutora não leva os alunos a contrastarem suas respostas, a chegarem às suas conclusões, durante a troca. $\mathrm{O}$ tutor restringe o seu papel ao de avaliador: 
6.

Tutora

colocado: 08/agosto/2011 às $22: 20$

Olá, Rodrigo,

Gostei muito do seu exemplo, mas fiquei um pouco confusa. Porém, isso é normal porque estamos tratando de aspectos governamentais os quais não são tão simples de serem

explicados a partir do marketing.

Pelo que entendi, o DNIT está responsável por cuidar da infraestrutura de transportes do país, sendo que, para tanto, contrata empresas nacionais e internacionais que são, na verdade, quem realiza as obras físicas, para que os serviços de transportes possam acontecer. É isso? 88

Neste caso, temos que é necessário a construção de alguns produtos, como estradas, ferrovias e hidrovias, para que a prestação do serviço principal, que é oferecer à população vias de transporte de bens e pessoas.

O preço desse serviço varia conforme a via que será utilizada (que não se resume à construção, mas é composta também pela própria manutenção dessas vias). Os custos de tais obras influenciam no orçamento da área, sendo que cada uma delas varia conforme seu local, extensão e características específicas. Logo, o pedágio é um tipo de preço para essa manutenção, as passagens de trem são outra forma. Em alguns casos, no preço está incluso um pequena parcela referente ao retorno do investimento.

A praça está correta, ou seja, ele é oferecido em todo o território nacional.

A promoção ou divulgação dessas vias é feita por diversos meios de comunicação, dependendo da escolha dos dirigentes da região.

Quando analisamos os processos, observamos que para realizar os serviços, há todo um processo de contratação, até porque essas obras demandam também a realização de licitações, por serem pagas com dinheiro público. Então a divulgação do edital e a realização da licitação fazem parte do processo da prestação de um serviço maior. E dada a importância e complexidade dessa fase, é preciso estar sempre atento a todos os procedimentos relativos a esse processo, de forma que o mesmo não venha a ser invalidado.

Eu gostaria que você finalizasse esta revisão, indicando qual a formação das pessoas que trabalham no DNIT e que preparam essas contratações, bem como qual o pefil físico dos escritórios onde esse pessoal trabalha.

Abraços,

7.

Tutora

colocado: 08/agosto/2011 às $22: 35$

Olá, Ramon,

Vamos à justiça federal!

Sua apresentação ficou bem completa. Achei muito interessante quando você comentou 
sobre as novas varas, para agilizar os processos. Isso é um exemplo de revisão de processos e procedimentos, exatamente para identificar pontos frágeis, de forma a substitui-los, eliminá-los ou mesmo já definir um plano de contingência caso ocorra algo errado.

Achei também muito interessante a questão da comunicação interna e da comunicação externa. Você entendeu muito bem os conceitos!

Parabéns pelo exemplo!

Resultados como esse apontam para a dificuldade de se pensar um modelo de aprendizagem centrado na mudança do papel do tutor. Os alunos também mostram dificuldade para alterar seus paradigmas.

Um deles é o de apenas "marcar presença" na sala, respondendo à tutora apenas com emoticons. Isso faz com que o tutor assuma o seu papel de instrutor não só quanto a tarefas, prazos, mas também quanto à aceitabilidade de uma contribuição naquela atividade, como mostra o exemplo abaixo:

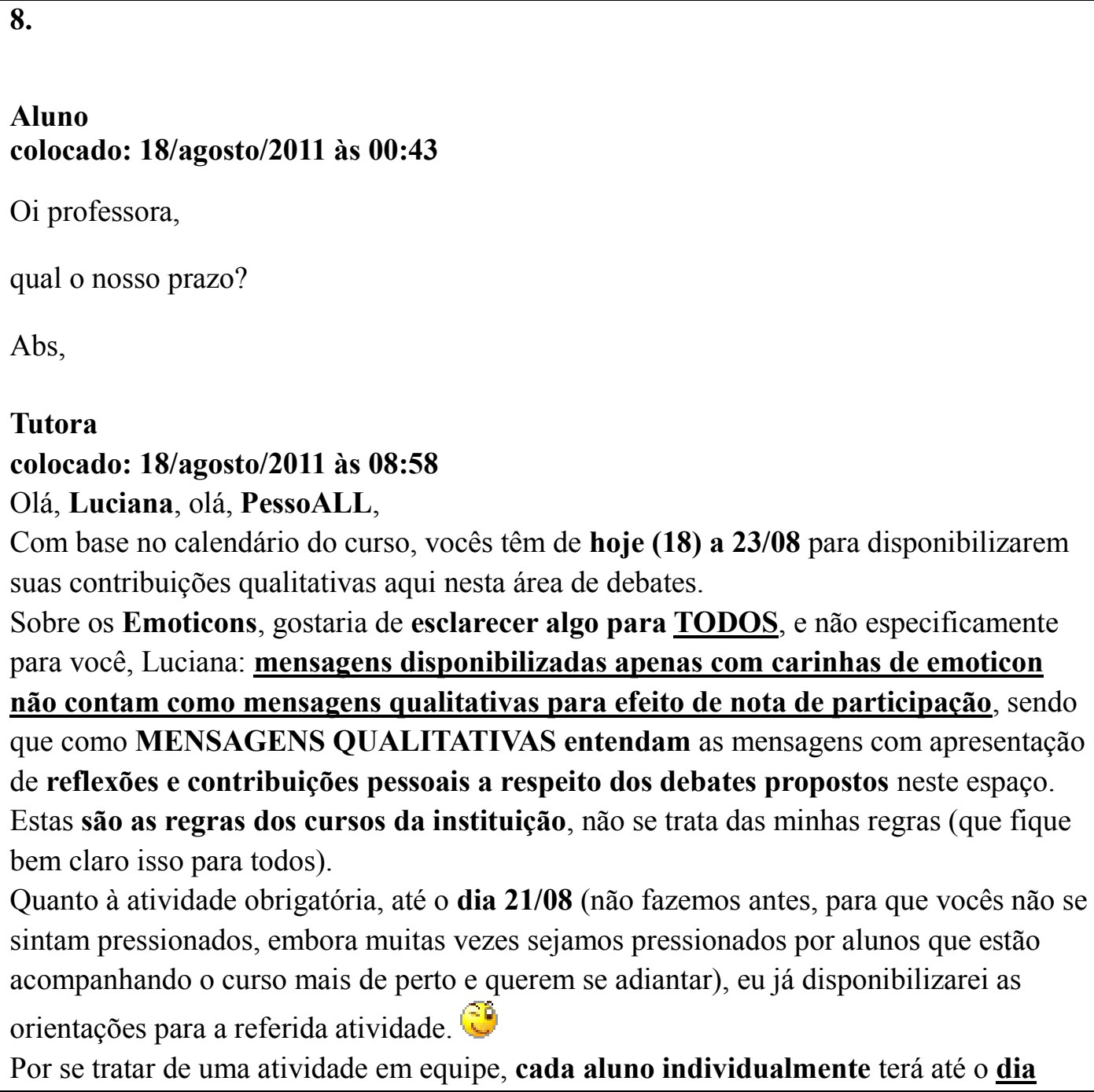


$\underline{\text { 26/08 }}$ para produzir e entregar sua atividade individual, a qual deverá ser disponibilizada no ambiente de debates da atividade disponibilizado na área de discussões de cada equipe. E cada equipe terá até dia 02/09 para me enviar o trabalho final geral do grupo, já finalizado, por mensagem particular. 9

A participação de todos é essencial, portanto organizem suas agendas e suas participações! th

Abraços a todos!

Como mostra o exemplo, a tutora, dirigindo-se à aluna e à turma, dá esclarecimentos de diferentes ordens. Alguns deles se referem à atividade de condução do curso: prazos, atividades, procedimentos que devem ser seguidos/atendidos. Outro aspecto dessa condução é o que diz respeito à natureza da contribuição: a tutora caracteriza o que são contribuições qualitativas que contam como participação (reflexões, posições sobre questões levantadas para debate). Nesse sentido, a tutora restringe o uso de carinhas de emoticon apenas como suporte de ações, posições.

\section{- Editor}

Para se compreender o papel de editor, é preciso levar em consideração outro papel assumido pelo tutor no decorrer do curso: o de espectador. A mensagem abaixo foi publicada ao final das apresentações dos alunos sobre os textos recomendados. Como se pode ver, o tutor assume o papel de mero acompanhante da conversa:

9.

Tutora

colocado: 08/agosto/2011 às $21: 47$

Olá, Turma,

Confesso que estou impressionada com vocês! Muita bem impressionada!

Sobre os textos, como são análises particulares, eu prefiro acompanhar, lembrando apenas que agora estamos começando a vivenciar os primeiros efeitos da globalização e de uma série de decisões em função do cenário que se estimava ter.

A própria situação da Europa, da Comunidade Européia, da Grécia, da Espanha e do Reino Unido parece nos mostrar cenários que merecem ser reexaminados.

Então, vou me dedicar a comentar os exemplos dados por vocês aqui, para que 
aprofundemos as teorias.

Então, vamos aos comentários!

Uma vez que o aluno ainda tem como destinatário-alvo o tutor, o papel de espectador da conversa pode levar à suposição de que as contribuições não foram consideradas. Acreditamos que essa possa ser uma razão para o tutor assumir o papel de editor das contribuições dos alunos ao final de cada atividade. Nesse papel, ele só faz resumir o que cada um disse:

\section{0.}

\section{Tutora}

colocado: 16/agosto/2011 às 20:34

\section{Olá, PessoALL,}

Parece-me que já estão aquecidos para as discussões deste módulo! Vamos às contribuições já disponibilizadas sobre como implementar as estratégias de marketing no setor público!

O João comentou sobre a importância da conscientização das organizações quanto às ações de responsabilidade social e reflete sobre o quanto se espera de ganho de imagem com estas ações. Aqui eu gostaria de mencionar um estudo de caso. Há uma empresa chamada Interface, produtora de tapetes e carpetes, que desde de 1995 decidiu rever todo seu processo produtivo, de forma a substituir ou minimizar o uso de matérias primas que danificassem o meio ambiente. Paralelo a isso, todos os empregados passaram (e continuam passando) por um processo de educação para a sustentabilidade. Quando questionado sobre a razão que o levou a fazer essas modificações, o CEO da empresa respondeu que foi as novas demandas dos consumidores. Porém, ele acabou se dedicando pessoalmente à causa quando teve que estudar sobre o tema para fazer o lançamento do projeto. Aqui eu reforço o que comentei anteriormente em meu comentário às suas colocações: empresas (públicas ou privadas) são formadas PESSOAS! Tenham isso sempre em mente!

A Rita identificou algumas palavras-chave ao longo da leitura dos quatro textos disponibilizados: planejamento estratégico, plano. Porém, o que mais se destacou para ela foi a necessidade de revisão constante desse planejamento para reajustes do "percurso", das ações a serem adotadas. E questionou as razões de não identificarmos fidelização, principalmente quanto aos candidatos a cargos públicos. Aqui eu diria que se trata de uma pergunta bem interessante e complexa. Quem se arrisca a comentar?

O Marcos comentou o texto "Ineficiência Premiada", definindo-o como o retrato da 
administração pública. E destacou a importância da criatividade e inovação nesse processo de planejamento, mencionando o foco na eficiência, a eficácia, a efetividade. Prêmios como o "Concurso de Inovação na Gestão Pública", da ENAP, são exemplos a serem seguidos noutras esferas, noutros Poderes, segundo ele.

Já o José comentou também a questão de fidelização do cliente-cidadão, afirmando que a grande vantagem é que "fidelizar um consumidor, nesta situação, não existe concorrência, já que o mandato é único". Porém, não sei se é mais fácil, como ele afirmou! Também concordou que vale à pena aprofundar a discussão sobre o tema.

O Jonas escolheu comentar sobre o TCU, colocando que considerou inovadora a postura do TCU no caso descrito e aguarda para ver se conseguirão aplicar, dado o poder que as empresas de telecomunicações têm junto ao setor público.

Ele também apresentou um exemplo sobre o atendimento de uma dessas "teles", refletindo sobre a eficácia da estratégia adotada junto aos seus vários públicos. Vale conferir suas considerações!

O João retomou as discussões, respondendo às minhas considerações sobre as empresas serem formadas por pessoas. De fato, as empresas são muito mais do que a soma das individualidades e agem pelo interesse do grupo, como ele bem colocou. Por isso, é preciso que alguns passem a pensar diferente, a partir de diferentes referências, embasando suas ações no interesse geral, como deveria ser. Por isso destaquei essa questão. Trata-se de uma mudança cultural, que é muito mais complexa e demorada de se realizar. Muito bem colocado, João!

O João também questionou o Mateus sobre a existência de uma dicotomia na "instituição voltada ao controle" e gestão focada no resultado. O Marcos vai refletir e responder depois!

E vamos em frente!

Abraços a todos!

Esse extenso turno da tutora ilustra o modo como ela edita as respostas dos alunos, privilegiando especialmente o que foi dito, sem, no entanto, estabelecer ou criar oportunidade para que os alunos estabeleçam relações entre as contribuições.

\section{2 .2}

\section{Papel de mediador}


No programa analisado, vemos que, dado o conjunto de papéis do tutor (MERTON, 1968, p. 111), ela assume também o papel de mediador entre os alunos e o suporte técnico, o conteudista e a própria instituição.

Embora o tutor, em sua autoapresentação, tenha orientado sobre uma interlocução direta entre alunos e suporte técnico, o que se observa é que os alunos encaminham para o tutor os problemas técnicos, e ela acaba por aceitar o papel de mediadora na relação alunos-suporte.

Na mensagem abaixo, pode se ver que a tutora se coloca à disposição para entrar em contato com o suporte para esclarecer o problema de acesso a alguns slides pelos alunos:

11.

\section{Tutora}

07/agosto/2011 às 23:24

Prezados Rodrigo, Jonas e demais Alunos,

Amanhã pela manhã eu ligarei diretamente ao pessoal do suporte, para verificar a razão dos problemas ainda não terem sido resolvidos.

Eu já havia verificado todos os slides, mas para mim, todos estão funcionando. Eu rechequei a lista do Rafael e estão todos ok. Por isso pensei que estava resolvido. Então, falarei diretamente e depois volto com vocês.

Acredito que até o final da tarde eu tenha algum retorno deles, mas eu os manterei informados

Abraços e até lá!

Parece que, na percepção dos alunos, o problema do acesso influencia no andamento de sua aprendizagem. Sendo o tutor responsável por isso, caberia/cabe a ele buscar uma solução para o problema. Isso é reforçado, quando o tutor também é procurado para resolver problemas relativos ao material do conteúdo:

12.

Tutora

colocado: 08/agosto/2011 às 08:54

Olá, Rodrigo,

Continuo tentando conseguir o gráfico junto ao autor do curso, que foi quem indicou o 
arquivo, pois também não consegui localizar na internet, que fornece apenas o texto em si.

Abraços,

Nesse caso, vemos que a tutora se propõe a mediar a relação alunos/conteudista, e mais, que ela tem a iniciativa de resolver por si só o problema.

Outra forma de mediação envolve a relação alunos/coordenação, instituição. Um exemplo é o caso de reclamações:

13.

\section{Aluno}

colocado: 22/agosto/2011 às 12:01

Colegas e tutora,

Começo apoiando os comentários do Jardel em relação a quantidade excessiva dos textos complementares e o conteúdo desatualizado dos mesmos.

Já tinha reclamado isso na disciplina anterior e coloquei no formulário de avaliação, mas pelo visto não surtiu muito efeito pois esta disciplina comete os mesmos erros no meu ponto de vista, isto é, textos complementares excessivos e de conteúdo desatualizado.

Abraços

\section{Tutora}

colocado: 22/agosto/2011 às 13:04

Olá, Ricardo,

Entendo que já tenha colocado a questão quanto às datas dos textos na disciplina anterior, mas as coisas não são tão ágeis assim.

O processo de escolha e substituição de textos demanda pesquisa, análise e autorização dos autores para que os textos sejam aqui disponibilizados.

Reforço que é realmente importante que façam essa solicitação junto à coordenação, mas as modificações em si não serão feitas já para as disciplinas seguintes exatamente por não depender apenas da vontade da instiuição, mas também dos autores dos eventuais textos escolhidos.

Abraços, 
Como mostra o exemplo, temos uma reclamação por parte dos alunos quanto à atualização dos textos complementares da disciplina. Neste caso, apesar de ter de "responder" em nome da instituição, já que o assunto foi trazido para sala de aula, ela orienta o aluno a procurar a coordenação do curso, explicando que a solução do problema não é tão simples quanto parece.

Nos casos listados, vemos que a tutora assume papéis que não estão relacionados à aprendizagem em si. O fato de ter de esclarecer dúvidas técnicas em um programa que possui um suporte técnico desqualifica a figura do tutor, relegando-o a uma função de helpdesk.

Do mesmo modo, o fato de ela não ser a autora do conteúdo a coloca num status mais baixo, o que não impede que ela seja vista como a responsável por esse conteúdo.

A sua projeção como mediadora nas relações com a coordenação também apontam para o modo como os alunos a veem como responsável pelo curso.

Ao assumir o papel de mediadora entre diversas áreas, a figura de tutor fica desqualificada, pois seu papel fica camuflado entre o de técnico e o de mediador do trabalho de outrem (SOUZA, 2013, p. 45).

\section{2 .3}

\section{O papel de animador/motivador}

Em um ambiente virtual de aprendizagem, em que as possibilidades tecnológicas possibilitam maior autonomia dos alunos, o incentivo à participação é crucial para a desejada aprendizagem. Por isso, é de suma importância que o tutor crie um ambiente amigável, que promova um clima de cooperação entre os participantes com a finalidade de proporcionar a coesão do grupo.

Na mensagem abaixo, por exemplo, vemos uma mensagem de incentivo à participação dos alunos:

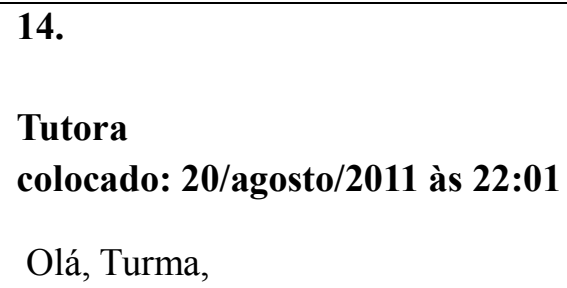


Vejo que continuam animados, o que me deixa muito feliz!

Aguardo mais reflexões, para poder apresentar comentários mais completos!

Abraços a todos!

Nesse caso, o início das discussões do módulo havia começado há menos de três dias. Então, a tutora prefere externar sua satisfação com as contribuições já realizadas, mas ainda não acha que seja o momento de comentá-las. Notamos ainda que ela se mostra feliz com animação (participação da turma).

Outra forma de motivar a participação dos alunos é por meio de elogios às contribuições:

15.

\section{Tutora}

colocado: 10/agosto/2011 às $22: 29$

Olá, João, olá, PessoALL, João, isso é que chamo de almoço produtivo e reflexivo! Parabéns pelos comentários!

Tenho que confessar que em função da temática sobre a qual estamos tratando, tenho que me limitar mais a "ouvi-los", sem poder emitir muito a minha opinião.

Contudo, gostaria de saber de você, João, e dos demais colegas, quais seriam os principais desafios ou empecilhos para se organizar e profissionalizar um pouco mais os vários órgãos do setor público?

Em nossa ROL de abertura, alguns de vocês defenderam que deveria acabar a estabilidade. E outros defenderam que se não houvesse um mínimo dessa estabilidade de pessoas técnicas concursadas, não haveria como construir algo mais consistente e sólido, o que não deixa de ser verdade.

E não se trata de algo que possa ser resolvido do dia para a noite ou com aumento de verba. Logo, como vocês iniciariam esse processo em seus setores ou em alguns dos órgãos que conhecem?

Aguardo mais contribuições!

Como mostra o exemplo, a tutora parabeniza um aluno por sua contribuição, elogiando a qualidade de seus comentários (João, isso é que eu 
chamo de almoço produtivo. Parabéns pelos comentários!). Nesse caso, ela também usa a contribuição para lançar uma nova questão, pegando como gancho um ponto que foi tratado na reunião on-line (chat) e incentivando mais uma vez a participação da turma.

Observamos ainda que ela se preocupa em publicar mensagens com tom de acolhimento, como no trecho a seguir:

\section{6.}

Tutora

colocado: 13/agosto/2011 às $22: 09$

Olá, Turma,

Confesso que estou duplamente feliz com a qualidade dos debates: primeiro por ter a honra de ser tutora de vocês e, segundo, por ser cidadã e poder ter a honra de acompanhar servidores públicos como vocês desenvovlendod ebates e reflexões de tão alto nível! Parabéns a todos! th $^{2}$

Nesse caso, o elogio da tutora não se restringe apenas às contribuições dos alunos, mas ultrapassa a esfera meramente acadêmica. Ela expressa sua satisfação com a atitude dos alunos quanto às suas reflexões, demonstrando que sua preocupação não se limita ao desempenho de seu papel como educadora, mas colocando-se como cidadã nesse processo de desenvolvimento de servidores públicos.

Por fim, um outro modo de criar um ambiente amigável é a utilização de recursos não verbais, como os emoticons, pela tutora. Como estamos em um ambiente virtual, em que contato visual não existe, ela não conta com as possibilidades próprias do modelo presencial na interação com os alunos (como, por exemplo, gestos, entonação da voz, expressão facial, etc.). Observarmos, então, que em todos os seus turnos de fala, a tutora se utiliza de emoticons para suprir essa lacuna.

17.

Tutora

colocado: 03/agosto/2011 às $17: 28$ 


\section{Olá, Rodrigo,}

Vou verificar isso e depois dou o retorno a vocês!

Obrigada por me alertar sobre o fato!

18.

Tutora

colocado: 03/agosto/2011 às $17: 32$

Olá, Paulo,

Desculpe-me, não entendi sua solicitação!

Você quer que eu explique a frase, a relação entre a empresas de telecomunicações -

governo - fundos de pensão, ou a correlação entre a frase e esse "trio"?

Aguardo seu retorno para poder responder.

Como mostram os exemplos, a tutora chega a utilizar um emoticon por sentença, demonstrando certo exagero. Por se tratar de recursos para denotar emoções (alegria, surpresa, aprovação, etc.), causa certo estranhamento que dado emoticon seja o "oposto" do anterior, oscilando, de certa forma, de um extremo ao outro.

Nesse caso, podemos observar as dificuldades em gerenciar as restrições próprias da tecnologia. $\mathrm{Na}$ tentativa de criar um ambiente mais humanizado, vemos que a tutora esbarra com restrições próprias do registro escrito.

Cabe ressaltar que os alunos fazem pouco uso desse recurso, se comparado ao da tutora, utilizando, principalmente para "marcar" presença em sala. 


\section{Organização da troca interacional e o modelo pedagógico}

Como já apontado na literatura (GARCEZ, 2008 p. 20), a organização da troca interacional é sensível ao contexto, sendo localmente produzida. No caso de um ambiente virtual de aprendizagem, essa organização é sensível à mediação tecnológica e ao modelo pedagógico que orienta as ações dos participantes. Neste capítulo, apresentamos os padrões interacionais, na seção 6.1, o mais recorrente, cujas trocas estão centradas no tutor e; na 6.2, o mais raro, cujas trocas estão centradas no aluno.

\section{1}

\section{Padrão 1 - Troca centrada no tutor}

Apesar de a EAD assumir que os recursos tecnológicos podem favorecer uma mudança no papel do professor de transmissor de conhecimento para facilitador da construção do conhecimento, o que se observa é a recorrência de um modelo pedagógico centrado no professor/ensino.

- O primeiro turno das trocas

Cabe ao tutor abrir o curso, abrir um módulo, abrir uma discussão. Sendo assim, cabe sempre a ele iniciar o turno. $\mathrm{Na}$ mensagem a seguir, podemos observar o turno de iniciação do tutor ao abrir o primeiro módulo da disciplina.

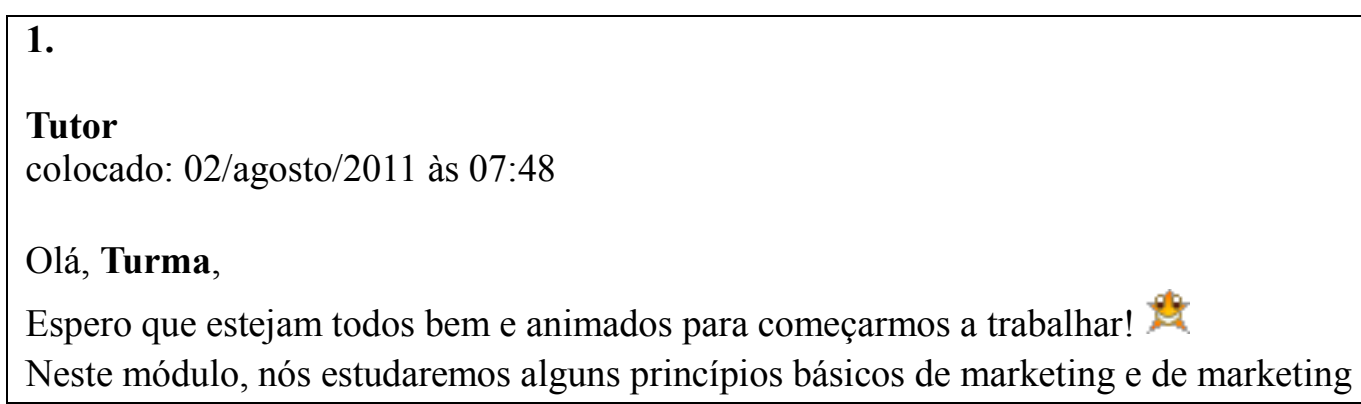


de serviços, bem como as principais diferenças entre o marketing no setor público e no setor privado.

Para iniciarmos nossas discussões, além da leitura do conteúdo da apostila, eu disponibilizo aqui 3 textos de leitura complementar, ligados à temática que estamos tratando:

D8FZA_1-1-1_sejamos_logicos.doc

FA5CD_1-1-2_entre_globalizacao_emprego.doc

512AD_1-1_briga_brasil_telecom_levanta.doc

Como não há uma atividade obrigatória prevista para este módulo, gostaria que aproveitássemos até pelo menos $\mathbf{0 6 / 0 8}$, para aprofundarmos o conteúdo teórico deste módulo aqui nesta área de debates!

Conto com a participação e contribuição de todos aqui neste espaço! Abraços e até mais!

Nessa mensagem, a tutora se dirige a turma de forma geral e realiza ações de diferentes naturezas.

A organização da sua fala envolve as seguintes ações: 1) ela abre com uma palavra de incentivo à participação, buscando o engajamento da turma; (2) logo em seguida, ela apresenta o assunto do módulo (princípios básicos de marketing e de marketing de serviços); (3) depois ela apresenta o material de apoio; (4) por fim, faz uma proposta de atividade; (5) fecha, do modo que abriu, incentivando a participação e (6) faz as despedidas.

Por um lado, a metodologia de ensino explora as possibilidades da tecnologia, disponibilizando links, deixando assim alguns arquivos para download como sugestão de leitura complementar além do conteúdo já disponível. Por outro lado, a proposta de atividade, que é o ato principal da sequência de atos, é formulada de modo vago (aprofundamento) e não incita os alunos a responderem ao pedido ou a responderem fora do enquadre da discussão proposta.

\section{- O segundo turno da troca}

A resposta dos alunos a essa iniciação mostra que eles não se sentem chamados a participar do processo. Apresentamos, abaixo, alguns tipos de resposta a essa sequência: 


\section{a) A fala social}

2.

Aluno 1

colocado: 02/agosto/2011 às 12:03

Pois é...e lá vamos nós....

Aluno 2

colocado: 02/agosto/2011 às 12:49

Vamos lá!

Aluno 3

colocado: 02/agosto/2011 às $16: 16$

\%

Como podemos observar, os alunos se limitam a respostas apenas à ação de incentivo à participação ("Pois é... e lá vamos nós....", "Vamos lá"), utilizando a forma verbal no plural. Um deles, inclusive, utiliza apenas uma mensagem não verbal (emoticon). São, portanto, respostas focadas na relação social.

b) A dúvida técnica

3.

Aluno 4

Colocado: 02/agosto/2011 às 14:58

Tutora,

No texto complementar: "Sejamos Lógicos" é mencionado um gráfico onde mostra a taxa de crescimento real do PIB (média 2003-05) e a carga tributária em porcentagem do PIB (2002-04), mas este gráfico não está no arquivo disponibilizado.

Você ainda vai disponibilizar o gráfico ou não será necessário para o contexto?

Att, 
Aqui, a resposta é relacionada à atividade em si, mas traz uma dúvida técnica, que poderia ser dirigida ao suporte do programa e não ao tutor em sala de aula. Na verdade, essa dúvida poderia ter sido enviada por mensagem particular em vez de ter sido trazida no fórum de discussão do módulo, pois também não contribui para o aprofundamento do tema.

\section{c) $\mathrm{O}$ resumo}

Os alunos que respondem ao pedido da tutora podem fazê-lo simplesmente resumindo o que leram:

4.

Aluno 5

colocado: 07/agosto/2011 às $23: 38$

Olá prof ${ }^{a}$, gostei muito dos textos sugeridos para leitura.

Importante abordagem sobre o papel do governo nos fundos de pensão, da mesma forma se deve refletir sobre a proteção aos setores que mais geram emprego em nossa economia.O texto do economista Delfin Netto mostra o qual papel Estado deve ter na economia, e mostra algo crucial receitando para o nosso Brasil "redução da carga tributária e aumentar, paralelamente, a eficiência da maquina estatal, é essencial para acelerar o crescimento e executar políticas públicas que reduzirão a enorme desigualdade de oportunidades"

\section{Aluno 6 \\ colocado: 08/agosto/2011 às $22: 26$ \\ Olá pessoal}

Estou muito impressionada com o nível em que chegou essa discussão. realmente , o nível está muito elevado. Sinto em não ter participado antes. Mas nunca é tarde!!!

Então, dentre os três textos sugeridos, o que mais me impressionou foi "Sejamos lógicos".

Nesse texto, é muito interessante o posicionamento de "ficar em cima do muro", ou seja, não aderir totalmente à economia socialista e nem totalmente à economia de mercado. A questão é que nenhum deles ainda comprovou qual é a melhor forma de administrar a economia. Na verdade, tem de haver um trabalho em conjunto das empresas privadas com as políticas públicas do governo. 
E ainda para aumentar essa tendência, há a questão "Estado grande deixa o país sem espaço para crescer" onde, às vezes, para se ter um crescimento, devemos dar 1 passo para trás para darmos 2 passos para frente. Isso quer dizer que, às vezes, devemos diminuir o investimento governamental para equilibrar as contas, diminuir o consumo e afastar alguns fantasmas como a inflação.

E chegou-se à conclusão de que para haver um crescimento tanto na economia quanto na igualdade de oportunidades entre as pessoas, deve-se haver uma redução da tributação ao mesmo tempo em que o aumento da eficiência da máquina governamental.

\section{d) pedido de esclarecimento}

Uma outra forma de responder a pedido de tarefas é o pedido de esclarecimento que também evidencia uma educação centrada no tutor.

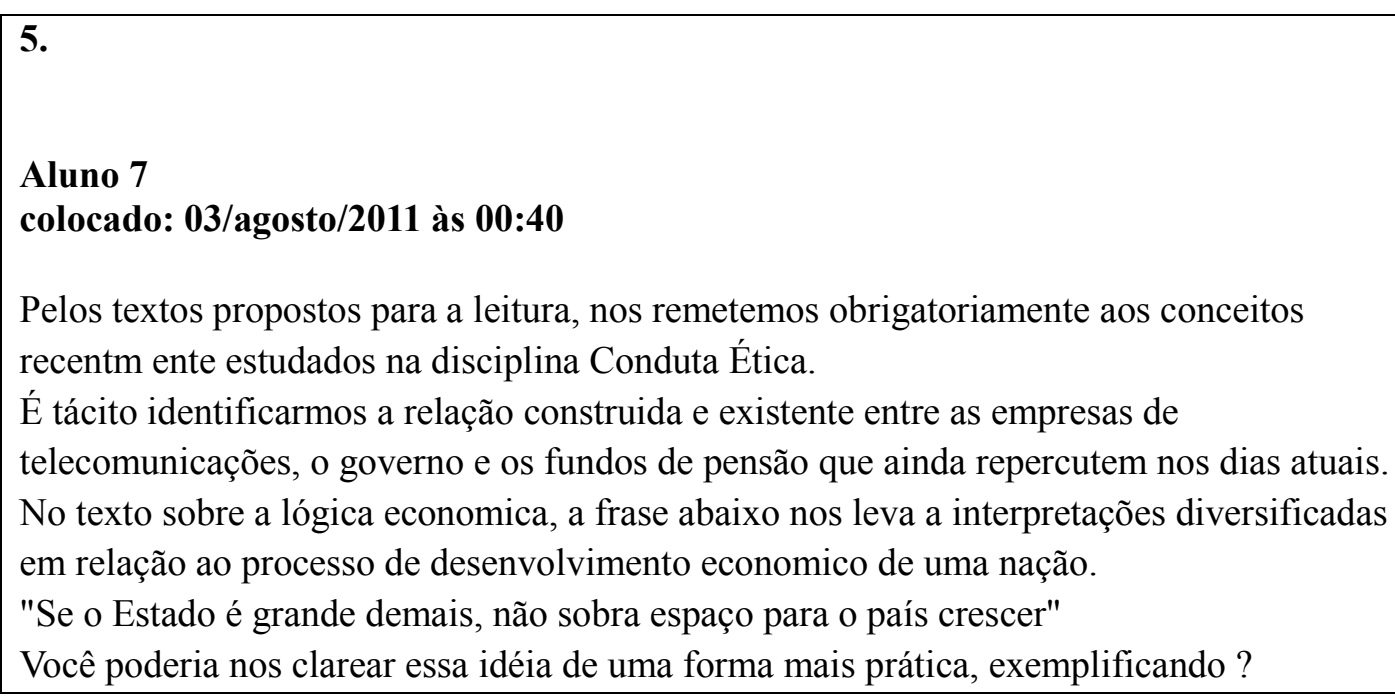

Nessa mensagem, o aluno se dirige, especificamente, à tutora ("você poderia nos clarear essa ideia..."). O uso do "você" implica que só há um referente possível. Nenhum aluno se autosselecionou para responder à questão, o que ratifica a assimetria interacional e o status do tutor como o único que detém o conhecimento.

\section{e) a iniciação para o debate (potencial de ser resposta e iniciação para outros)}


Algumas respostas mostram que os alunos também fazem iniciações, quando se posicionam, fazem avaliações que podem ser gatilhos para debate.

6.

Aluno 8

colocado: 03/agosto/2011 às 11:58

Professora,

na leitura complementar apresentada, me chamou especial atenção o texto "Entre a globalização e o emprego" por ele retratar de um cenário de emprego que sofreu alterações, mas que, justamente pelos efeitos da globalização, pode voltar a qualquer momento.

Devemos levar em conta que, entre a data em que o texto foi escrito (2007) e hoje, tivemos uma grave crise econômica (2009) e que, hoje, vivemos um período de recuperação. Diferentemente do que ocorria há quatro anos, a indústria não está mais fechando postos de trabalho e o setor da construção civil ganhou fôlego, se firmando como um dos que mais emprega atualmente.

Esse aparente momento de "máquinas a todo vapor", impulsionado pelos eventos esportivos dos próximos anos, no entanto, corre riscos. Com a turbulência norteamericana das últimas semanas (EUA ameaçando dar calote... esse mundo está de pernas para o ar mesmo), o medo dos economistas brasileiros é que essa onda venha bater nas bandas de cá e todo esse cenário positivo que se construiu a partir de 2009 volte a patamares anteriores.

Ou seja: nesse nosso mundo globalizado, o texto de 2007, ligeiramente desatualizado, pode voltar a fazer total sentido na semana que vem. Basta que os ecos dessa nova crise que se anuncia cheguem até aqui. Como dizem por aí, nesse caso, tudo voltaria a ser o reverso do que era antes...

\section{Aluno 9 \\ colocado: 03/agosto/2011 às $18: 10$ \\ É preciso tomar cuidado...}

Não há país hoje que não tenha uma mescla de serviços com a indústria, daí vem a expressão serviços industriais. Há nisso uma imbricação importante. Acabou a chamada teoria dos três setores - agricultura, indústria e serviços. Hoje se tem uma coisa muito mais interpenetrada - por exemplo, a agroindústria.

Acho que estamos paralisados diante de um falso impasse: ou aceitamos as imposições geradas pela nova ordem econômica internacional ou, do contrário, a alternativa é o desemprego. 
Novamente, vemos que o centro de atenção dos alunos é o tutor (professora). É para ele que o aluno fala. A sequência de resposta, no entanto, é mais rica: (1) o resumo é só uma abertura para uma discussão (na leitura complementar apresentada, me chamou especial atenção o texto "Entre a globalização e o emprego" por ele retratar de um cenário de emprego que sofreu alterações, mas que, justamente pelos efeitos da globalização, pode voltar a qualquer momento); (2) expõe um ponto de vista, contrastando a data da publicação do artigo e a realidade atual; (3) faz uma avaliação sobre o texto e lança uma tese que pode gerar uma discussão.

O mesmo acontece na contribuição do Aluno 9, no entanto, nenhum colega ou o próprio tutor respondeu às iniciações feitas pelos dois alunos. Parece que só quem pode iniciar é o tutor.

Um outro modo de se ver a centralidade do tutor no modelo de ensino envolve a questão da sequencialidade temporal (em relação à ordem das contribuições). Vemos que o primeiro aluno fala sobre emprego (ainda que fazendo um alerta para uma mudança inesperada); o outro, sobre desemprego (a alternativa é o desemprego). O último não o faz no sentido de um contraponto ao que foi dito anteriormente, mas, novamente, desconsiderando o que foi dito. Logo, a sequencialidade é orientada para a iniciação do tutor e não para a resposta do colega.

Percebemos ainda que o par adjacente sempre se forma com a iniciação da tutora e a resposta do aluno a ela. Em alguns raros casos, verificamos uma sequência que podemos considerar como paralela, em que os alunos se falam.

Se tomarmos o modelo convencional de aula como referencial, a falta de sequencialidade na organização dos turnos pode ser considerada algo estranho a esse contexto, pois ainda que um aluno não recupere a fala do colega, seu turno, com certeza, terá relação com algum turno anterior, já que ele não fala sozinho, ou ao esmo, o que parece ocorrer aqui.

Outra questão que se destaca é em relação às possibilidades e às restrições inerentes à tecnologia. Ao mesmo tempo que ela possibilita a participação de forma assíncrona em um fórum de discussão, também contribui para a quebra de 
coerência, já que se pode facilmente resgatar o que foi dito anteriormente e fazer uma contribuição quando (e como) o aluno quiser.

Em alguns casos, o aluno também se projeta como detentor do saber, é aquele em que identificamos uma sequência de exposição que se assemelha a uma aula.

7.

Aluno 9

colocado: 03/agosto/2011 às $18: 15$

Guardada a devida proporção, há 150 anos, quando os novos processos de produção abriam a perspectiva de uma profunda intensificação do trabalho e enormes ganhos de produtividade, tecnicamente era possível uma jornada muito menor que a praticada no período. Embora isso fosse factível, as jornadas variavam entre 16 e 18 horas por dia e em geral contavam com a presença de crianças e adolescentes no interior das fábricas. Foi necessário um amplo processo de luta, que envolveu diferentes forças sociais, políticas, científicas e econômicas, bem como uma crise de proporções até então desconhecida, duas Guerras Mundiais e uma alternativa efetiva ao capitalismo liberal para que fosse aberta a perspectiva de transformar a possibilidade técnica em realidade.

Faço essa digressão para mostrar que o capital é sempre reativo.

Estamos ingressando num capitalismo pós-industrial em que a produtividade é cada vez mais sustentada no trabalho imaterial e, a despeito disto, vale lembrar que o país que mais cresce no mundo é a China, inclusive no plano das tecnologias avançadas, e parte deste crescimento é função do rebaixamento da remuneração da força de trabalho a um nível inimaginável.

\section{Aluno 10 \\ colocado: 04/agosto/2011 às $17: 27$}

\section{Aluno 9,}

Grandes economistas consideram a chamada Era de Ouro, no final do século IX, o período em que se chegou mais próximo do capitalismo liberal teorizado por Adam Smith, David Ricardo e outros. Nessa época houve intenso fluxo de capital e também de trabalho entre os países. Nunca as barreiras comerciais foram tão baixas e o comércio mundial foi tão integrado, nos termos das "vantagens comparativas".

Como bem colocaste, isso trouxe consequências sociais incontornáveis e lutas que garantiram direitos mínimos aos trabalhadores. No período entre guerras, a menor elasticidade dos salários desbalanceou o sistema e colocou todo o senso comum da época, ou seja, consenso de que o mercado se adapta e reestabelece o equilíbrio, em xeque. Essa foi a época em que, finalmente, o jovem Keynes foi levado a sério.

O estado do bem estar social é consequência desse processo, e as suas disfunções, a 
medida que os Estados passaram a ser muito maiores, como ineficiência dos serviços, défits governamentais enormes, gestão extremamente burocrática; foram motivo para uma guinada em direção à diminuição da participação do Estado na economia, mais ou menos na década de 90 .

Porque toda essa história? Porque queria contribuir ao debate com a minha opnião de que o capitalismo é cíclico, as vezes mais liberal e as vezes menos, mas nunca foi abandonado ou deixou de melhorar nesses 2 séculos de existência. A globalização, em termos de capitais, não tem o mesmo efeito social negativo que teve em seu último pico, porque agora temos muito mais regras sociais e também porque aprendemos com o passado.

A economia mundial vive sim, há dois séculos uma dicotomia entre eficiência e bem estar social (qualquer semelhança com o Taylorismo não é coincidência!), mas ao meu ver caminha na maioria das vezes em direção ao ponto ótimo, não contra.

Desculpem!!! Escrevi demais!!!

Dica de livro excelente, que trata disso: O Capitalismo Global, de Jeffry A. Frieden.

Abraço a todos!!!

O Aluno 9 já havia respondido anteriormente, porém ele publica uma nova mensagem, fazendo o que ele enquadra como uma digressão (revisão histórica). Trata-se, no entanto, do argumento para defender sua tese sobre o capitalismo (é sempre reativo). Embora o turno dele mencione a questão industrial, trazida pela colega anterior, vemos que, novamente, ele discorre sobre o assunto sem exatamente criar uma relação entre o que está dizendo e a opinião do colega, fazendo com que sua contribuição mais pareça uma aula expositiva sobre o assunto.

Observarmos aqui um caso de sequencialidade paralela: o Aluno 10 responde ao Aluno 9. Tomando a tese do colega como iniciação, ele se dirige ao colega (João) e retoma sua fala ("como bem colocaste"). Ainda que se demore um pouco para expor sua opinião, apresenta claramente qual é a sua contribuição para o debate ("porque queria contribuir ao debate com a minha opinião de que o capitalismo é cíclico”).

Outro aspecto desejado, mas pouco encontrado nos dados, é o de contribuir com material para a discussão. O Aluno 10 aproveita seu turno de fala para trazer uma sugestão de leitura aos colegas, postura que denota que ele entende que pode ser agente na construção do seu próprio conhecimento e do outro. 


\section{- Terceiro turno: resposta do tutor}

A resposta do tutor às contribuições dos alunos pode ser de três tipos: a) avaliação; b) ausência de avaliação e nova iniciação; c) resumo.

\section{a) Avaliação e o padrão IRA}

A avaliação faz parte de um padrão interacional identificado pelos linguistas Sinclair e Couthard como IRA: iniciação, resposta e avaliação. Como vimos, o tutor inicia com uma proposta de discussão; o aluno responde a essa proposta e, em seu terceiro turno da sequência, o tutor avalia a resposta.

Como Garcez chama a atenção (2006, p. 69), trata-se de um método eficaz e econômico não só para apresentar ou verificar informações novas mas também para levar o aluno a ser um mero reprodutor do conhecimento.

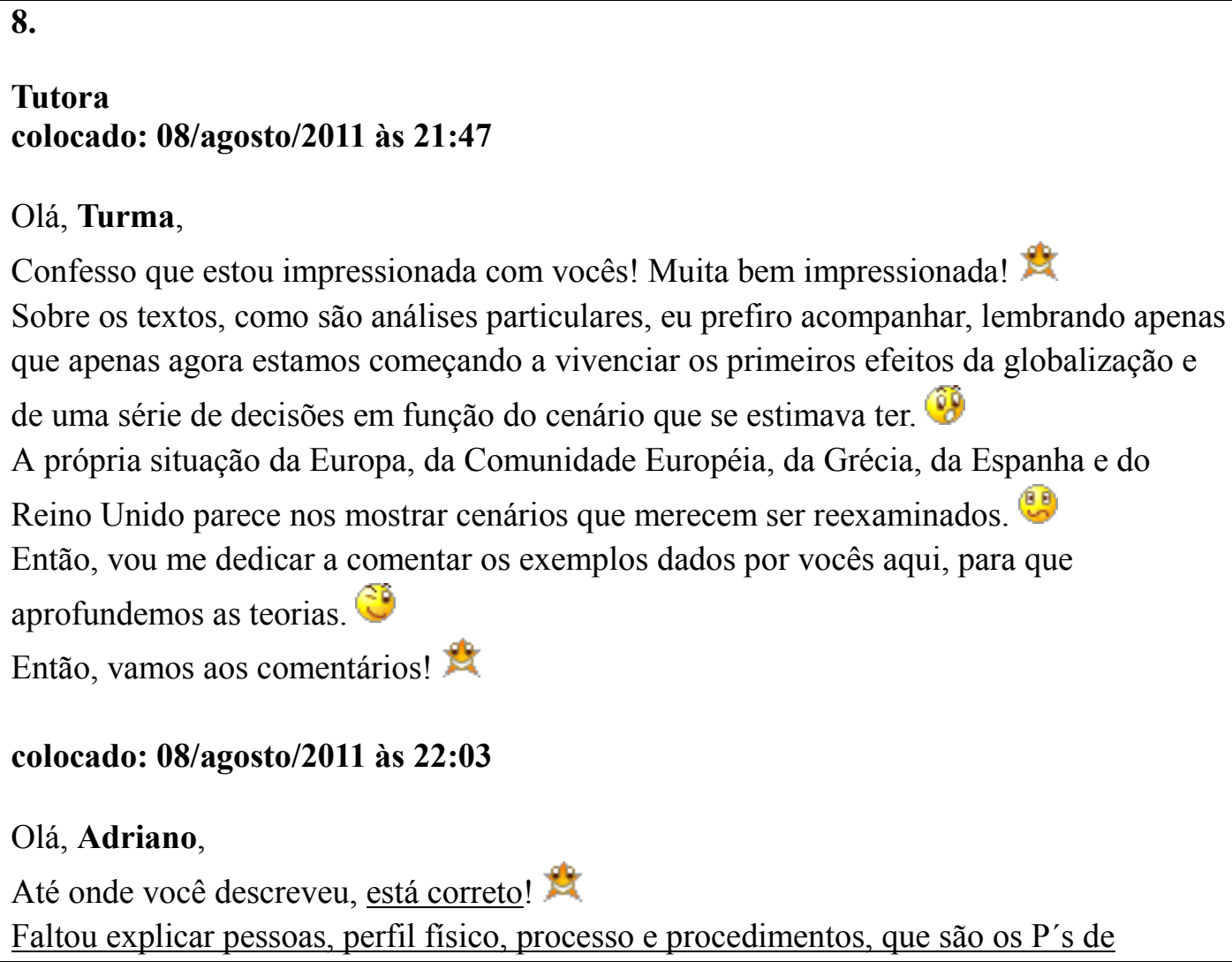


serviços especificamente.

Na verdade, eles oferecem um conjunto de vários "pequenos" serviços que fazem parte de um serviço maior que é oferecer a oportunidade de votar.

Logo, podemos observar vários procedimentos que fazem parte de vários processos ligados a cada pequeno serviço ou a cada pequena parte do serviço.

Quanto às pessoas, qual a formação mínima que precisam ter para trabalhar no órgão?E como são as instalações dos locais onde os serviços são prestados?

Aguardo a complementação!

colocado: 08/agosto/2011 às $22: 20$

Olá, Rodrigo,

Gostei muito do seu exemplo, mas fiquei um pouco confusa. Porém, isso é normal porque estamos tratando de aspectos governamentais os quais não são tão simples de serem explicados a partir do marketing.

Pelo que entendi, o DNIT está responsável por cuidar da infraestrutura de transportes do país, sendo que, para tanto, contrata empresas nacionais e internacionais que são, na verdade, quem realiza as obras físicas, para que os serviços de transportes possam acontecer. É isso?

Neste caso, temos que é necessário a construção de alguns produtos, como estradas, ferrovias e hidrovias, para que a prestação do serviço principal, que é oferecer à população vias de transporte de bens e pessoas.

$O$ preço desse serviço varia conforme a via que será utilizada (que não se resume à construção, mas é composta também pela própria manutenção dessas vias). Os custos de tais obras influenciam no orçamento da área, sendo que cada uma delas varia conforme seu local, extensão e características específicas. Logo, o pedágio é um tipo de preço para essa manutenção, as passagens de trem são outra forma. Em alguns casos, no preço está incluso um pequena parcela referente ao retorno do investimento.

A praça está correta, ou seja, ele é oferecido em todo o território nacional.

A promoção ou divulgação dessas vias é feita por diversos meios de comunicação, dependendo da escolha dos dirigentes da região.

Quando analisamos os processos, observamos que para realizar os serviços, há todo um processo de contratação, até porque essas obras demandam também a realização de licitações, por serem pagas com dinheiro público. Então a divulgação do edital e a realização da licitação fazem parte do processo da prestação de um serviço maior. E dada a importância e complexidade dessa fase, é preciso estar sempre atento a todos os procedimentos relativos a esse processo, de forma que o mesmo não venha a ser invalidado.

Eu gostaria que você finalizasse esta revisão, indicando qual a formação das pessoas que trabalham no DNIT e que preparam essas contratações, bem como qual o pefil físico dos escritórios onde esse pessoal trabalha. 
Abraços,

colocado: 08/agosto/2011 às $22: 35$

Olá, Ramon,

Vamos à justiça federal!

Sua apresentação ficou bem completa. Achei muito interessante quando você comentou sobre as novas varas, para agilizar os processos. Isso é um exemplo de revisão de processos e procedimentos, exatamente para identificar pontos frágeis, de forma a substitui-los, eliminá-los ou mesmo já definir um plano de contingência caso ocorra algo errado.

Achei também muito interessante a questão da comunicação interna e da comunicação externa. Você entendeu muito bem os conceitos!

Parabéns pelo exemplo!

No primeiro turno dessa série, a tutora reafirma que prefere apenas acompanhar as análises sobre os textos e não fazer comentários. Mais uma vez, ela denota entender que seu papel, em alguns momentos, limita-se apenas em "acompanhar" as participações (veremos mais adiante, quando analisarmos os diversos papéis no próximo capítulo). Logo em seguida, ela passa a avaliar as participações dos alunos que "realizaram a atividade". Ela não faz uma avaliação geral ou relaciona uma contribuição à outra, mas avalia uma por uma, dirigindo-se especificamente a cada aluno. Seu feedback sobre cada contribuição é predominantemente avaliativo ("gostei de seu exemplo", "a praça está correta", "parabéns pelo seu exemplo").

Em alguns momentos, ela pede complementação ou faz uma correção ( "Faltou explicar pessoas, perfil físico, processo e procedimentos, que são os P's de serviços especificamente.”, ou "Eu gostaria que você finalizasse esta revisão, indicando qual a formação das pessoas que trabalham no DNIT e que preparam essas contratações, bem como qual o perfil físico dos escritórios onde esse pessoal trabalha").

Em nenhum momento, ela faz uma relação entre as análises dos alunos, comparando o P de um órgão a outro ou chama a atenção para as especificidades (o P que falta), mesmo trazendo a diferença do conceito que já é conhecido na área privada para a pública (quais seriam as diferenças, as semelhanças, etc.). 
A análise mostra que os alunos não são chamados a refletir sobre as diferenças entre os órgãos. A resposta dela se restringe apenas à avaliação ("está correto", "faltou...", etc.).

Durante a análise dos demais módulos, podemos observar que, de certo modo, a sequência IRA é recorrente no ambiente. Em todos, a iniciação do tópico de discussão é dada no formato de um pedido indireto, de uma solicitação que os alunos comentem alguns textos indicados. Esse pedido, no entanto, não contribui para o debate, para a reflexão, para o diálogo com vias à construção de um espaço de aprendizagem colaborativa, já que o aluno não precisa do engajamento no seu segundo turno. No terceiro turno da tutora, não observamos a tentativa de “costurar" as intervenções, cabendo a ela apenas avaliar ("gostei”, "está correto").

Corroborando com essa percepção, vemos que a tutora sempre fecha o módulo com uma avaliação geral sobre o que foi dito:

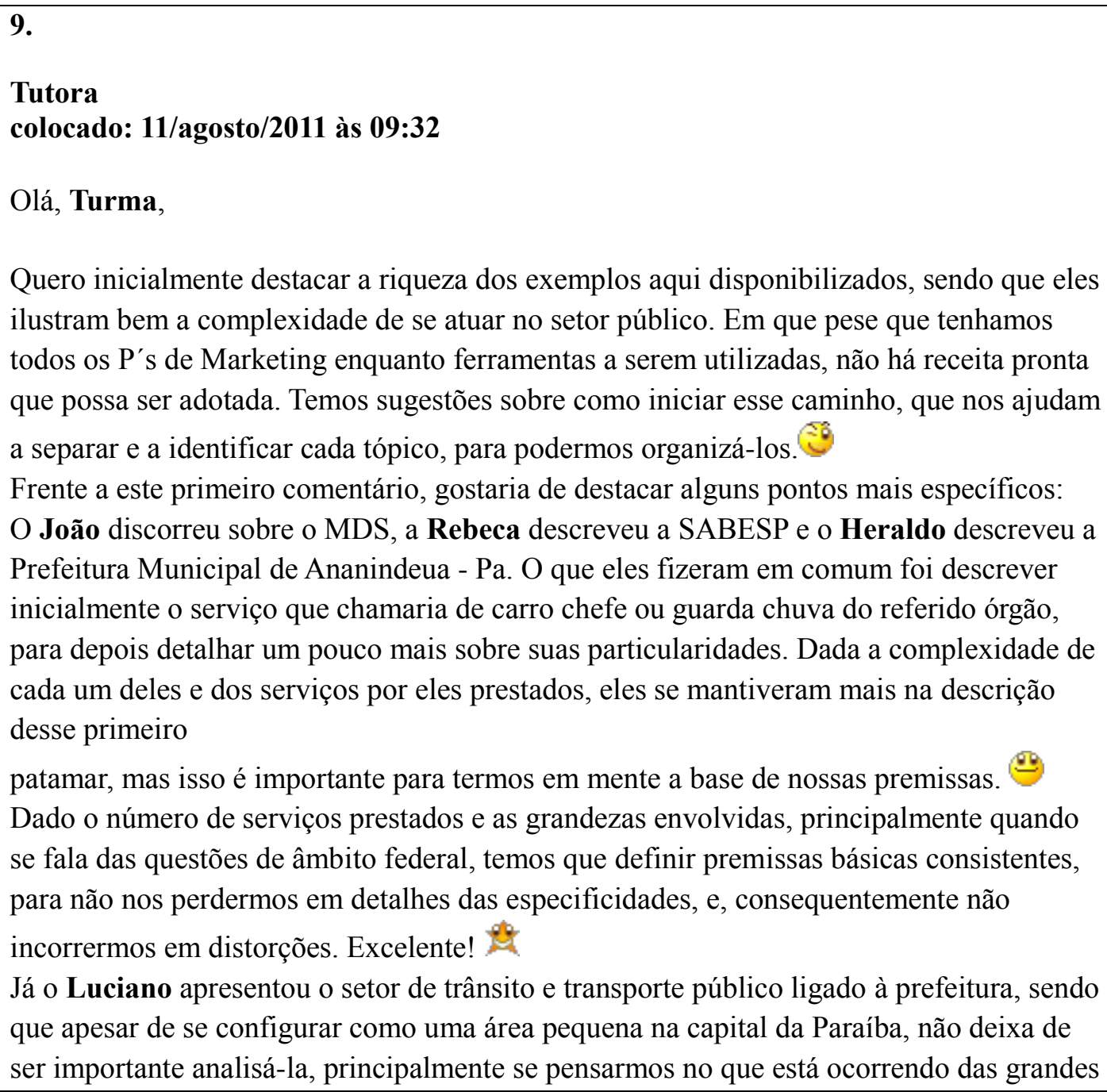

Quero inicialmente destacar a riqueza dos exemplos aqui disponibilizados, sendo que eles ilustram bem a complexidade de se atuar no setor público. Em que pese que tenhamos todos os P's de Marketing enquanto ferramentas a serem utilizadas, não há receita pronta que possa ser adotada. Temos sugestões sobre como iniciar esse caminho, que nos ajudam a separar e a identificar cada tópico, para podermos organizá-los.

Frente a este primeiro comentário, gostaria de destacar alguns pontos mais específicos: O João discorreu sobre o MDS, a Rebeca descreveu a SABESP e o Heraldo descreveu a Prefeitura Municipal de Ananindeua - Pa. O que eles fizeram em comum foi descrever inicialmente o serviço que chamaria de carro chefe ou guarda chuva do referido órgão, para depois detalhar um pouco mais sobre suas particularidades. Dada a complexidade de cada um deles e dos serviços por eles prestados, eles se mantiveram mais na descrição desse primeiro

patamar, mas isso é importante para termos em mente a base de nossas premissas. Dado o número de serviços prestados e as grandezas envolvidas, principalmente quando se fala das questões de âmbito federal, temos que definir premissas básicas consistentes, para não nos perdermos em detalhes das especificidades, e, consequentemente não incorrermos em distorções. Excelente!

Já o Luciano apresentou o setor de trânsito e transporte público ligado à prefeitura, sendo que apesar de se configurar como uma área pequena na capital da Paraíba, não deixa de ser importante analisá-la, principalmente se pensarmos no que está ocorrendo das grandes 
cidades, como São Paulo.

(...)

Parabéns a todos pelas excelentes reflexões e exemplos!

Abraços,

A expectativa de que um padrão interacional do tipo IRA é subjacente pode ser evidenciada no modo como os alunos encerram suas contribuições:

10.

Aluno 11

07/agosto/2011 às 15:42

Escolho o DNIT (Departamento Nacional de Infraestrutura de Transportes), órgão onde trabalho, para acrescentar ideias ao debate.

O DNIT cuida da infraestrutura dos transportes em todo o país (rodovias, ferrovias e hidrovias), por causa da sua abrangência no país, o órgão tem que contratar empresas particulares de engenharia para executar os serviços de melhorias, recuperação, implantação, duplicação, etc... na área de transportes.

O próprio órgão não consegue sozinho realizar estas tarefas. Então os seus clientes são empresas de engenharia nacionais e internacionais.

O Produto que o DNIT oferece para as empresas de engenharia são as obras de infraestrutura de transportes (rodovias, ferrovias e hidrovias).

O Preço dos serviços seguem tabelas de insumos e variam de região para região devido ao acesso da matéria prima para a execução das obras (aço, cimento, brita, etc...) Obras nas regiões norte e nordeste podem ter preços maiores do que obras iguais na região sudeste, por exemplo por causa do frete dos materiais.

Em relação a Praça, o DNIT tem Superintendências em todos os estados brasileiros para facilitar a fiscalização dos serviços executados e ajudar na execução das obras.

Promoção, por se tratar da principal autarquia do governo federal em obras de infraestrutura de transportes, basta anunciar o edital das obras que as empresas tem interesse imediato pelos serviços. Basta anúncios em jornais de grande circulação e Diário Oficial da União.

Os procedimentos básicos seriam:

1. definição de qual rodovia federal apresenta problemas sérios por exemplo de sinalização (radares para redução de acidentes); (Produto e Praça)

2. Definição do preço de acordo com o mercado, fazer a licitação; (Preço e Promoção) 
3. Contratar a melhor proposta para o governo e realizar a obra/serviço.

$\underline{\text { Não sei se era exatamente isso que foi proposto! Qq dúvida estou por aqui! }}$

Att,

\section{Aluno 12}

colocado: 08/agosto/2011 às 00:59

Escolho o Cartório Eleitoral onde trabalho,

-PRODUTO: atendimento diversos aos eleitores - emitir, revisar, transferir, regularizar o título eleitoral e certidões - atendimento aos advogados quantos aos processos eleitorais, entendendo que o Cartório Eleitoral é o juízo de primeiro grau na Justiça Eleitoral; -PREÇO: todos os serviços elencados acima são gratuíto.

-PRAÇA: nós temos um local que chamamos Casa da Democracia, onde se encontra os 6 Cartórios de Cuiabá-MT, no Centro da Capital atendemos no Ganha Tempo e temos também atendimento via internet.

-PROMOÇÃO: usamos vários tipos de mídia para comunicar com o Cliente Cidadão, internet, televisão, rádio e jornal.

\section{Professora, espero estar certo!}

Adriano Cassemiro Silva - TRE-MT

\section{Aluno 13}

colocado: 08/agosto/2011 às 19:17

Cara Luci,

Pretendo discorrer sobre parte das atividades da Prefeitura de São Paulo, no âmbito da Subprefeitura Sé - Centro da Cidade.

Prefeitura do Município de São Paulo:

http://www.capital.sp.gov.br/portalpmsp/homec.jsp

Secretaria de Coordenação das Subprefeituras:

http://www.prefeitura.sp.gov.br/cidade/secretarias/subprefeituras/

$(\ldots)$

P-1 = Praça:

A Subprefeitura Sé é responsável pela administração pública dos seguintes distritos: Bom Retiro, Santa Cecília, Consolação, Bela Vista, República, Liberdade, Cambuci e Sé, localizados na região central da cidade de São Paulo, em um território de $26,2 \mathrm{~km}^{2} \mathrm{com}$ uma população residente de aproximadamente 374.000 habitantes e uma população visitante de aproximadamente $2.500 .000 /$ dia.

P-2 = Preço:

Arrecadado nos impostos e taxas.

P-3 = Promoção/Comunicação:

Além da divulgação institucional da Prefeitura, todas as Subprefeituras e demais órgão 
divulgam suas ações por meio de campanhas, imprensa de forma geral e INTERNET. Muitas das empresas contratadas para a prestação de serviços junto a Prefeitura se obriga a divulgação dos planos de trabalho e frequencia dos serviços.

P-4 = Produto/Serviços:

- Varrição de Ruas;

- Limpeza de Bueiros;

- Tapa-Buraco;

- Áreas de Risco;

- Recuperação de Superfícies Pichadas;

- Limpeza de Piscinões;

- Túneis e Passagens Subterrâneas;

- Limpeza de Córregos;

- Árvores;

- Grama;

- Ecopontos;

Pessoas:

Empresas terceirizadas contratadas por licitação pública. Fiscalização, quanto a execução e qualidade dos serviços, exercida pelos servidores públicos.

Perfil físico:

O centro da Cidade de São Paulo, é muito sensível fisicamente quanto as ações da Prefeitura. A realidade comercial e de visitantes trabalhadores [2.500.000/dia] promove um impacto muito grande em toda a região, e os problemas de trânsito, locomoção e demais advindos desta massa migrante em muito compromete as ações de zeladoria no centro. Boa parte dos serviços, são executados a noite, contudo os residentes [374.000] passam a sofrer com esta situação. Este estado de coisa é agravado com a incidencia de chuvas, manifestações da população ou eventos.

Procedimento:

Definido no termo de referência e mantendo pessoal habilitado para a execução dos serviços.

\section{Processo:}

Atendendo os termos de referência exigidos pela Prefeitura.

CONSIDERAÇÕES:

Em que pese todas as tentativas de ser prestar um bom serviço, muitas das vezes a Prefeitura é criticada pela população visto as demandas locais serem maiores que a capacidade de atendimento instalada.

As limitações orçamentárias e o grupo de leis, inclusive de responsabilidade fiscal estreitam as possibilidades de atendimentos das demandas sociais.

O processo de contratação, retenção de servidores assim como a gestão do conhecimento é relegada a um plano que não atende os avanços exigidos pela globalização e interação da sociedade no quesitos inofrmação e de qualidade. 
Espero ter atendido o proposto na inicial.

Como mostram os negritos (nossos), os alunos deixam claro que estão em busca da resposta certa e de domínio apenas do professor. Com esses fechos, eles abrem a possibilidade de um outro par adjacente: pergunta (estou certo?)/avaliação (Sim/Não mais justificativa).

\section{b) ausência de avaliação e abertura de nova iniciação}

Uma outra forma de realizar o terceiro turno é o de omitir uma avaliação ou propor questões para debate a partir das contribuições dos alunos. Ela não aproveita os pontos polêmicos para de fato criar um ambiente de discussão, de coconstrução do conhecimento.

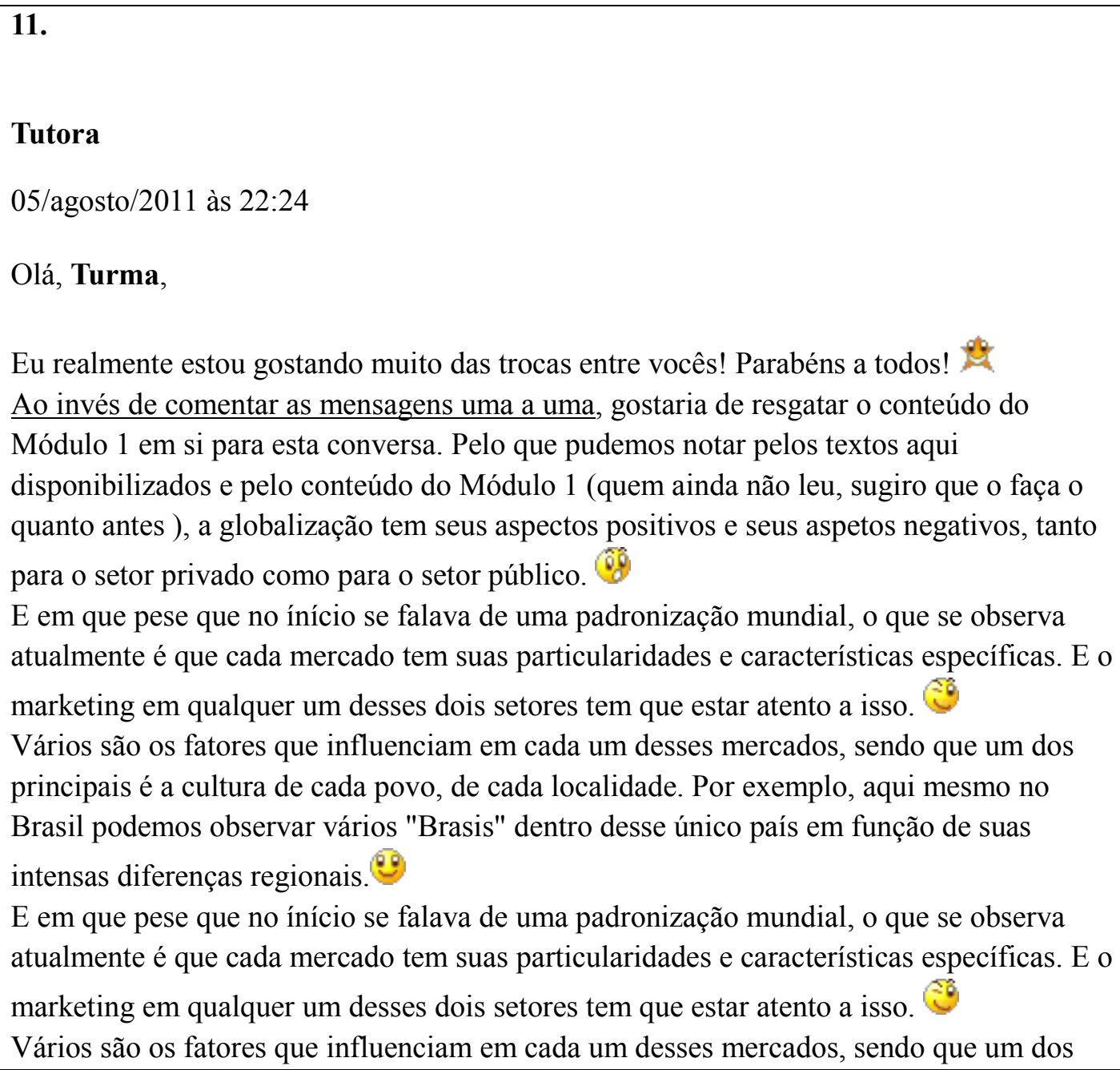


principais é a cultura de cada povo, de cada localidade. Por exemplo, aqui mesmo no Brasil podemos observar vários "Brasis" dentro desse único país em função de suas intensas diferenças regionais.

Frente a esse contexto e com base no que falamos em nossa ROL de abertura sobre os 4 P's de marketing (Produto/Serviço, Preço, Praça e Produção) e dos 4 P's de serviços, gostaria de saber como vocês descreveriam esses oito $\mathrm{P}^{\prime} \mathrm{s}$ a partir de um órgão público, o qual pode ser onde trabalham ou outro que escolham exemplificar.

SUGESTÃO DE DEBATE: Peço que descrevam brevemente o serviço público que escolheram analisar, quais seriam as bases da definição do preço desse produto, qual a praça onde ele é oferecido, como se dá a promoção/comunicação do mesmo junto aos cidadãos, quais seriam as formações específicas das pessoas que o prestam, como seria o perfil físico da localidade onde são prestados e listem de 4-5 procedimentos básicos que compõem o processo dessa prestação de serviços.

Caso tenham alguma dúvida na montagem desse exemplo, não hesitem em me perguntar. 9.9 objetivo aqui é que passem a refletir sobre os $\mathrm{P}^{\prime} \mathrm{s}$ de Marketing junto à gestão pública, para que comecem a entender melhor como se dá isso.

A participação de todos é importante, pois os vários exemplos diferenciados mostrarão a vocês como não existe receita pronta e como a estratégia de cada um dos $P^{\prime}$ s está ligada às estratégias dos demais.

Aguardo suas contribuições!

Abraços a todos! Qualquer coisa, estou por aqui!

Como se pode ver, a sequência é constituída dos seguintes atos: 1) explicação indireta para a falta de avaliação (ao invés de comentar as respostas, gostaria de resgatar); 2) elogio como incentivo à participação; 3) exposição (resumo das informações dos textos); 4) iniciação (pedido de descrição da aplicação dos 8 Ps à área em que atuam; 5) orientação para a tarefa; 6) oferecimento para tirar dúvidas; 7) justificativa para a tarefa e para a participação; 8) a reiteração do pedido como fecho; 9) despedida e reiteração de oferecimento de apoio para a tarefa.

Observa-se, portanto, que, na sequência de atos que configuram o terceiro turno, o ato principal é o de iniciar uma nova proposta. A tutora não avalia os resultados nem inicia a partir das questões levantadas pelos alunos que poderiam ser aproveitadas para debate e reflexão.

Ainda que os especialistas em EAD defendam que a sala de aula deva ser participativa, um ambiente propício à aprendizagem colaborativa, o que vemos é que o tutor e os alunos não conseguiram se desvencilhar do paradigma tradicional. Por esse modelo, o professor propõe uma questão (inicia), o aluno apenas 
responde ao que foi perguntado (já preocupado em acertar a resposta) e, por fim, o professor avalia.

Ainda de acordo com esse paradigma, a fonte do saber é o tutor. É para ele que os alunos falam, a ele recorrem em casos de dúvida e dele esperam a legitimação de suas contribuições.

Uma outra evidência da falta de um modelo de construção coletiva da aprendizagem é o fato de os alunos não estabelecerem uma relação entre as respostas. Cada aluno, num diálogo com o tutor, descreveu o SEU caso e (“escolho o DNIT", "escolho o Cartório Eleitoral onde trabalho"...), sem perceber semelhanças, diferenças entre os casos, estabelecendo assim uma sequencialidade paralela.

\section{2 .2}

\section{Padrão 2 - Troca centrada no aluno}

Em contextos com assimetrias de interação, vemos que um participante detém o domínio da palavra e de sua distribuição (KOCH, 2010, p. 80). Embora na maior parte das vezes, a tutora seja aquela que abre o tópico, que inicia o turno, também encontramos exemplos em que a contribuição de um dos alunos frequentemente, sobre um assunto polêmico - inicia uma discussão.

Como pode se ver no exemplo abaixo, a partir da leitura de um dos textos sugeridos, uma aluna levanta e dirige uma questão a uma colega da turma:

12.

\section{Aluno 14}

colocado: 09/agosto/2011 às 12:46

Trago minhas considerações sobre o texto "Uma administração pública de cara nova". É difícil, em uma primeira leitura, não achar que os feitos do tal secretário não tenham sido absolutamente positivos na administração catarinense. Mas, como se trata de um político quase em campanha (conforme ele mesmo revela ao final da entrevista), achei que o texto carecia de um contraponto, já que parecia uma entrevista apenas elogiosa. Fiz uma rápida busca na internet e descobri que o então governador, descrito pelo secretário como "homem determinado, que planeja e cobra resultados", o mentor da reforma, foi muito criticado por onerar os cofres públicos ao criar muitos cargos comissionados e quase foi cassado suspeito de abuso do poder econômico, político e 
fraude.

Como os colegas sabem, não sou política nem tenho partido, mas sempre desconfio de modelos apresentados acriticamente, como a salvação da lavoura... Algum colega catarinense poderia dizer se as minhas desconfianças fazem sentido? Ou, apesar do contexto do que se desenrolou depois dessa entrevista, essa reforma adminstrativa trouxe reflexos positivos para a vida do cidadão?

Apesar de não ser uma constante no ambiente, podemos observar alguns casos em que os alunos não se restringem a apenas resumir textos ou destacar algum aspecto. Nesse caso, uma das alunas desconfiando dos dados fornecidos pelo texto, resolve pesquisar na internet mais informações sobre o caso. Não satisfeita com a resposta encontrada, ela busca auxílio na turma para obter mais informações, mostrando assim as possibilidades de trocas permitidas por esse ambiente de aprendizagem, não só em relação à busca de informação, fazendo do aluno agente de construção de seu próprio conhecimento, mas também na interação com colegas de diversas localidades com vias a uma troca efetiva, a construção conjunta do conhecimento.

$\mathrm{Na}$ mensagem abaixo, temos a resposta de outra colega a anterior. Verificamos que esta última segue seu exemplo da primeira e também busca outra fonte, trazendo mais informações para auxiliar no entendimento da questão:

13.

Aluno 15

colocado: 09/agosto/2011 às $21: 50$

Olá Maria,

Concordo plenamente com você. Não existem milagres.

Verifiquei que no TSE o tal governador estava com pedido de cassação de seu mandato e o seu vice também.

É óbvio que o secretário não falaria mal de seu governador porque, com certeza, ele o apoiaria nas próximas eleições.

E tem outro agravante, o sr. secretário que proporcionou a entrevista também não é uma pessoa de confiança. Verifiquei na Internet que ele está sendo acusado de receber propinas e que receberia $20 \%$ do valor de cada fatura de um contrato de $\mathrm{R} \$ 2.800 .000,00$.

É por essas e outras que não consigo confiar em políticos.

Abraços. 
Outro colega resolve também contribuir com o debate dando sua opinião acerca do assunto:

14.

\section{Aluno 16}

colocado: 10/agosto/2011 às $14: 00$

Boa tarde professora e colegas!

Novamente, gostei muito dos textos, embora continue surpreso com o tema central que os permeia.

Quanto ao primeiro texto, vou concordar com a colega Maria e duvidar. Ao meu ver fica a clara impressão de propaganda, de ser um texto até um pouco panfletário. Claro, como não conheço o contexto e nem o histórico do veículo de comunicação não vou além da impressão.

$(\ldots)$

Nesse caso, vemos, ainda que raro, um momento em que o debate, a conversa entre eles realmente se estabelece no ambiente. Os alunos observam a sequencialidade na alocação de seus turnos, fazendo clara relação com o que ele está dizendo e o colega anterior ("Concordo plenamente com você", "Quanto ao primeiro texto, vou concordar com a colega Patrícia e duvidar”). Existe uma relação clara entre um turno e outro quanto ao que está sendo discutido. Os alunos já não falam mais a esmo.

Várias reflexões também são trazidas ao ambiente ("É óbvio que o secretário não falaria mal de seu governador porque, com certeza, ele o apoiaria nas próximas eleições”). Os alunos fazem diferentes contribuições, seja com base em pesquisas em outras fontes de informação ("Fiz uma rápida busca na internet e descobri que o então governador... foi muito criticado por onerar os cofres públicos ao criar muitos cargos comissionados e quase foi cassado suspeito de abuso do poder econômico...", "Verifiquei que no TSE o tal governador estava com pedido de cassação de seu mandato e o seu vice também”) ou a partir de suas próprias opiniões ("Ao meu ver fica a clara impressão de propaganda, de ser um texto até um pouco panfletário"), permitindo a apresentação de diferentes pontos 
de vista.

Além disso, esse também é um raro exemplo em que eles também se dirigem um ao outro ("Olá Maria", "vou concordar com a colega Maria e duvidar"), no que parece ser uma busca efetiva para o estabelecimento de uma conversa entre os colegas, ainda que um deles inicie seu turno se dirigindo em primeiro lugar à professora ("Professora e colegas").

Podemos ainda observar que o conteúdo das contribuições em si também é bem diferente dos demais: as mensagens não se limitam apenas a resumir textos, ou a resposta a um enunciado, mas temos aqui contribuições realmente qualitativas ao debate. A troca de diversas informações e, até mesmo a apresentação de diferentes pontos de vista, finalmente proporcionaram uma discussão em sala, como uma das alunas conclui na mensagem abaixo:

15.

\section{Aluno 17 \\ colocado: 11/agosto/2011 às $00: 44$}

Olá Maria e Rebeca, discordo um pouco. Acredito que numa primeira leitura tive muitas dificuldades de entender o que ele fez e onde havia feito.rsrsrsr.

Creio que a grande dificuldade é demonstrarmos os métodos. Ele em momento nenhum cita como fez as mudanças, quais as ações tomadas. Acredito que para um gestão pública de cara nova deve ser apresentada como uma fórmula ou ainda uma receita de bolo.

Mas os fatos que você apresentou relata o que ocorre no Brasil. E outra...a professora citou o texto poderiamos muito bem achar maravilhoso e simplesmente acreditar. Mas essa busca de informação, essa pesquisa e o acesso a informaçãoa través da internet é o que propicia essas discussões.

Como mostra o exemplo, mais uma aluna adere ao debate. Ela também se dirige aos colegas, trazendo contribuições qualitativas, emitindo sua opinião sobre o assunto e tomando uma posição ("Creio que a grande dificuldade é demonstrarmos os métodos").

Cabe ainda destacar algo de extraordinário que ocorre nesse momento, que é a valorização na fala da aluna da coconstrução do conhecimento, reconhecendo 
que o empenho (busca de informação, pesquisa) é que torna possível a discussão, vendo-se também como agente nesse processo. 


\section{Considerações finais}

Da posição de educação de menor qualidade a sua atual configuração, a educação a distância no Brasil passou por muitas mudanças. Essas mudanças estão diretamente atreladas aos diferentes canais utilizados em cada uma das gerações da EAD. Se a primeira geração foi caracterizada pela oferta de cursos por correspondência a um público sem acesso a educação formal, a segunda se consolidou com o amplo alcance proporcionado por mídias de massa, como o rádio e a TV. A terceira, por sua vez, com a utilização do computador e, posteriormente, da internet, mudou a forma de distribuição da $\mathrm{EAD}$, e incluiu a interação no processo de ensino-aprendizagem. Hoje, essa modalidade já ocupa um novo patamar no cenário nacional, e atrai cada vez mais adeptos em busca de educação de qualidade aliada à flexibilidade de tempo e espaço.

No Brasil, o avanço da EAD está diretamente atrelado ao desenvolvimento de políticas públicas para a área e ao incremento das TICs. Desde 1996, a partir da criação da Lei de Diretrizes e Bases (LDB), diversas outras normas, instruções e regulamentações foram promulgadas e contribuíram para o oferecimento de um ensino de melhor qualidade a um maior número de pessoas. No que tange ao desenvolvimento das TICs, hoje, entre as diversas tecnologias, a internet já se configura como o segundo meio-mestre utilizado pelas instituições de educação a distância, estando atrás apenas do meio impresso (CENSO EAD.BR, 2012, p. 27). No entanto, apesar do que apregoa o determinismo tecnológico, o aprendizado, em um ambiente virtual, não depende só da tecnologia; depende do modo como os participantes interagem em função do uso que fazem das restrições e possibilidades da tecnologia.

Cabe ressaltar ainda que, no caso da EAD, o planejamento ocupa um lugar de destaque na implantação e na gestão de cursos a distância. Se antes a grande preocupação na concepção de soluções educacionais se restringia ao conteúdo e ao material didático, hoje se atribui uma importância cada vez maior ao acompanhamento e apoio ao aluno. Surge então a figura do tutor on-line como 
peça chave nesse cenário. Esta pesquisa teve como objetivo investigar os papéis desempenhados pelo tutor e o modelo pedagógico que subjaz ao modo como tutor e alunos gerenciam as possibilidades da tecnologia no fórum eletrônico de um curso de EAD.

Em relação aos papéis desempenhados, podemos observar que as atividades do tutor estão relacionadas a três grandes áreas principais: pedagógica, técnica e social. Apesar de a literatura apresentar quatro áreas (BERGE, 1995), entendemos que as ações relacionadas à área gerencial, na verdade, também compreendem atividades próprias da área pedagógica como, por exemplo, estabelecer prazos, acompanhar as entregas do aluno, etc., por isso preferimos trabalhar apenas com três áreas apenas. $\mathrm{Na}$ verdade, verificamos que todas as áreas estão a serviço da área pedagógica, sendo sempre orientadas em virtude da tecnologia.

Podemos verificar ainda que, ao investigarmos os papéis da atividade, tivemos uma melhor compreensão do papel desempenhado por esse profissional no ambiente virtual de EAD. Neste caso, observamos que o tutor desempenha três papéis da atividade: o de orquestrador; o de mediador e o de animador/motivador. E apesar da divisão por uma questão didática, entendemos que todos esses papéis constituem a atividade maior de facilitar o processo de construção de conhecimento.

Observarmos também que, ao desempenhar o papel de orquestrador, o tutor assume a centralidade nesta sala de aula, cabendo a ele conduzir todas as ações (apresentar o conteúdo, fornecer material, passar a atividade, avaliar, conduzir as trocas interacionais, etc.). Cabe destacar que essa centralidade no desempenho do papel nem sempre significa conduzir no sentido com vias a aprendizagem colaborativa.

Outro aspecto importante é que o papel de avaliador reforça seu lugar de centralidade nesse contexto, fazendo com que o aluno "trabalhe" para o tutor. É a ele inclusive que o aluno recorre para resolver os problemas, sejam de ordem técnica, de conteúdo, etc. Neste caso, é interessante notar que, embora exista um suporte técnico, o tutor toma para si certa responsabilidade em encontrar uma solução para o caso, acabando por um acumular um conjunto de papéis, que está relacionado com o suporte, com a coordenação, com o autor (MERTON, 1968, p. 110). 
Em relação ao modelo pedagógico que subjaz à organização das trocas interacionais, podemos observar que as iniciações também são centradas no tutor. É ele quem abre o tópico de discussão do módulo, da disciplina, da tarefa. O aluno, por sua vez, majoritamente, se dirige a ele, remetendo ao tutor as suas dúvidas, esperando sua avaliação, não se preocupando em estabelecer trocas paralelas com outros alunos e, consequentemente, não se afastando do modelo de aula tradicional. Além disso, a recorrência da sequência IRA (Iniciação-RespostaAvaliação) reforça a percepção da centralidade do tutor (e da avaliação) nesse contexto e a semelhança ao modelo de aula presencial tradicional.

É interessante ressaltar que, embora o pensamento permeie os princípios da EAD, que os cursos a distância sejam desenvolvidos objetivando que a aprendizagem assuma uma dimensão coletiva, sociointeracionista (SOUZA, 2013, p. 48), a simples inclusão da tecnologia no processo não garante que isto realmente ocorra. A tecnologia não faz tudo. Ainda que ela possa potencialmente ampliar a interação entre seus participantes, ela não determina se essa interação efetivamente ocorre (e como ocorre).

Os recursos da tecnologia não asseguraram uma metodologia centrada no aluno e na participação. O modo como os participantes gerenciaram suas restrições e possibilidades ainda está relacionado aos paradigmas desses participantes quanto ao que entendem como papel de professor e aluno. Neste caso, por exemplo, podemos notar que houve pouco uso de outras possibilidades da tecnologia, como links, vídeos, etc. Além disso, o modo como tutor e aluno "conversaram" espelha um modelo típico de uma aula presencial tradicional, o que mostra que os recursos são novos, mas os modelos são antigos.

Entendendo que a literatura apenas prescreve, esperamos que este estudo possa trazer contribuições para a formação de profissionais em ambientes de EAD. Importa ainda que outros trabalhos de pesquisa, em outros contextos de EAD, sejam desenvolvidos de modo a esclarecer quais seriam as competências interacionais a serem adquiridas para que esses profissionais se tornem efetivamente facilitadores da aprendizagem em ambientes de coconstrução do conhecimento. 


\section{Referências bibliográficas}

BERGE, Z.L.; COLLINS, M.P. Perceptions of e-moderators abour their roles and functions in moderating electronic mailing lists. Disponível em: http://emoderators.com/wp-content/uploads/modsur97.html. Acesso em: $30 \mathrm{de}$ nov. 2012.

BENTES, R. F.. A avaliação do tutor. In: LITTO, Frederic M; FORMIGA, Marcos (orgs.). Educação a Distância: o estado da arte. São Paulo: Pearson Education do Brasil, 2009.

BRASIL. Lei de Diretrizes e Bases no 9.394, de 20 de dezembro de 1996. Estabelece as diretrizes e bases da educação nacional. Diário Oficial da República Federativa do Brasil, Brasília, DF, 21 dez. 1996. Disponível em: http://portal.mec.gov.br/seed/arquivos /pdf/tvescola/leis/lein9394.pdf. Acesso em: 30 de nov. 2012.

CENSO EAD.BR: relatório analítico da aprendizagem a distância no Brasil 2010. São Paulo: Pearson Education do Brasil, 2012.

DENZIN, N; LINCOLN, Y. O planejamento da pesquisa qualitativa: teorias e abordagens. Porto Alegre: Artmed, 2006.

DURANTI, A. Linguistic anthropology. Cambridge: Cambridgen University Press, 1997.

FREITAS, A. S.; BERTRAND, Hélène; SILVA, José Roberto Gomes da. A implementação do e-learning nas escolas de gestão: um modelo integrado para o processo de alinhamento ambiental. Rio de Janeiro, 2009. 330p. Tese de Doutorado - Departamento de Administração, Pontifícia Universidade Católica do Rio de Janeiro. 
GARCEZ, P.M. A organização da fala-em-interação na sala de aula: controle social, reprodução de conhecimento, construção conjunta de conhecimento. Calidoscópio. v. 4, n.1., p. 66-80, 2006.

GARCEZ, P.M. A perspectiva da análise da conversa etnometodológica sobre o uso da linguagem em interação social. In: LODER, L.; JUNG, N. (orgs.). Falaem-interação social: introdução à análise da conversa etnometodológica. São Paulo: Mercado das Letras, 2008.

GARCEZ; P. M.; FRANK, I; KANITZ. A. Produção conjunta de conhecimento em um cenário de desenvolvimento de tecnologia. Veredas, v. 16, n.1, p. 166-184, 2012. Disponível em: http://www.ufjf.br/revistaveredas/files/2012/10/Art-12Garcez-Frank-e-Kanitz-final-10.05.12formatado.pdf. Acesso em: 30 de jan. 2013.

GOFFMAN, E. A situação negligenciada. In: RIBEIRO, B.; GARCEZ, P.(orgs). Sociolinguística interacional. São Paulo: Edições Loyola, 2002.

INFO. Brasil atinge 94,2 milhões de usuários de internet. Disponível em: http://info.abril.com.br/noticias/internet/brasil-atinge-94-2-milhoes-de-pessoasconectadas-14122012-32.shl. Acesso em: 30 de jan. 2013.

HUTCHBY, I. Conversation and technology: from the telephone to the internet. Cambridge: Polity Press, 2001.

KOCK, I. V. A inter-ação pela linguagem. São Paulo: Editora Contexto, 2010.

LEVINSON, S.C. Activity types and language. Linguistics, 365-399, 1979.

LÉVY, P.. Cibercultura. São Paulo: Editora 34, 2008.

LODER; L.; SALIMEN, P.; MÜLLER, M. Noções fundamentais de sequencialidade, adjacência e preferência. In: LODER, L.; JUNG, N. (orgs.). Fala-em-interação social: introdução à análise da conversa etnometodológica. São Paulo: Mercado das Letras, 2008. 
MAIA, C; MATTAR, J. ABC da EAD. São Paulo: Pearson Prentice Hall, 2007.

MARCUSCHI, L. A. Análise da conversação. São Paulo: Ática, 2007.

MERTON, R. Social theory and social structure. New York: Free Press, 1968.

MOODLE.ORG.BR. O que é o Moodle. Disponível em: https://moodle.org/about/. Acesso em: 30 nov. 2012.

MOORE, M; KEARSLEY, G. Educação a distância: uma visão integrada. Tradução de Roberto Galman. São Paulo: Thomson Learning, 2007.

OLIVEIRA, M. C.; PEREIRA, M. G. A interação tecnologizada em relações de serviço: um estudo do uso das possibilidades e restrições da tecnologia. Calidoscópio. v.3, n.2., p. 118-130, 2005.

SACKS, H; SCHEGLOFF, E. A.; JEFFERSON, G. Sistemática elementar para a organização da tomada de turnos para a conversa. Veredas, v.7, n. 1-2, p. 973. Tradução de SACKS, H; SCHEGLOFF, E. A.; JEFFERSON, G. A simplest systematic for the organization of turn-taking for conversation. Language, v.50, p. 696-735, 2003.

SARANGI, Srikant. Activity types, discourse types and interactional hybridity: the case of genetic counseling. In: SARANGI, S; COULTHARD, M. Discourse and social life. London: Pearson, 2010.

Reconfiguring sel/identity/status/role: the case of professional discourse studies. In: ARCHIBALD, J.; GARZONE, G. (orgs.) Actors, identities and roles in professional and academics settings: discursive perspectives. Berne: Peter Lang, p. 27-54, 2010. 
. Role hybridity in professional practice. In: ; POLESE, V.:

CALIENDO, G (eds.). Genre(s) on the move: hybridisation and discourse change in specialised communication. Napoli: Edizioni Scientifiche Italine (ESI), 2011.

SOUZA, E. V.; GASTALDO, E.; OLIVEIRA, M. C. Facework via e-mail: interação estratégica no ensino a distância. Rio de Janeiro, 2009. 160p. Tese de Doutorado - Departamento de Letras, Pontifícia Universidade Católica do Rio de Janeiro.

TAVARES, K. Os papéis e o trabalho do moderador de listas de discussão. Pesquisas em Discurso Pedagógico 3. Revista do IPEL, Pontifícia Universidade Católica do Rio de Janeiro, 2005, p. 72-88.

TELES, L.; ASHTON, S.; ROBERTS, T. The role of instructor in e-learning collaborative environments. Disponível em: http://www.techknowlogia.org /TKL_Articles/PDF/279.pdf. Acesso: 30 nov. 2012.

VIANNEY, J; TORRES, P.L; SILVA, E. A universidade virtual no Brasil. Tubarão: Ed. Unisul, 2003.

YIN, R. K. Estudo de caso: planejamento e métodos. Tradução de Ana Thorell. Porto Alegre: Bookman, 2010. 